\title{
Ocalenie Republiki. Charles de Gaulle wobec tradycji republikańskiej (1940-1946)
}

Wedle znanego określenia - używanego między innymi przez Raymonda Arona i Maurice'a Duvergera - V Republika ukształtowała się jako monarchia republikańska i miała połączyć zwaśnione tradycje ideowe ${ }^{1}$. W niniejszym artykule poddaję ten pogląd krytyce, albowiem uważam, że nie zbliża nas do rozpoznania źródeł i tożsamości V Republiki. Punktem wyjścia do ich wyjaśnienia jest świadomość zasadniczej roli, jaką odegrał de Gaulle w odbudowie ładu republikańskiego w czasie II wojny światowej i po wyzwoleniu Francji. Dzięki niemu powojenna Francja dokonała jednoznacznego wyboru na rzecz Republiki i wartości republikańskich - w takim znaczeniu, w jakim pojęcie to występuje we francuskiej myśli politycznej i rozwiązaniach ustrojowych.

\section{Republika à la francaise.}

1. Uniwersalne interpretacje Republiki nie wyjaśniają sensu, w jakim pojęcie to występuje we francuskiej myśli i tradycji państwowej. Teorie uniwersalne uznają republikę za ustrój alternatywny wobec dziedzicznego przekazywania władzy (w tym znaczeniu monarchie elekcyjne były republikami) bądź, w wersji pogłębionej, widzą istotę republiki w istnieniu wspólnoty obywateli wokół prawa i wartości ${ }^{2}$. Natomiast w przypadku Francji Republika jest przede wszystkim dziełem Rewolucji Francuskiej, która ustanowiła nową legitymację władzy opartą na specyficznie rozumianej idei suwerenności narodu i ukształtowała swe wartości w zasadniczej konfrontacji z tradycją monarchistyczną ${ }^{3}$. Maurice Agulhon pisze, że być republikaninem to przede wszystkim okazać się zwolennikiem władzy nie personalnej, nie dziedzicznej, nie dożywotniej

${ }^{1}$ R. Aron, Esej o wolnościach, Fundacja Aletheia 1997; M. Duverger, La monarchie républicaine (ou comment les démocraties se donnent des rois), Laffont 1974.

${ }^{2}$ B. Szlachta, D. Pietrzyk-Reeves, Republika, w: Słownik społeczny, WAM 2004, s. 1081-1117.

${ }^{3}$ J.L. Quermonne, République, w: O. Duhamel, Y. Mény, Dictionnaire constitutionnel, Presses Universitaires de France 1992, s. 921. 
i nie arbitralnej i dorzuca jednocześnie, że Republika oznacza identyfikację z „tradycją wywodzącą się z 1789 roku”4.

Republika we Francji ma zatem treść odrębną od uniwersalnych interpretacji i oznacza nie tylko sprzeciw wobec dziedzicznej transmisji władzy, ale również jej nową legitymację inspirowaną filozofią Jana Jakuba Rousseau i - co nie mniej istotne - pewien aksjologiczny projekt wyrażony w Deklaracji praw człowieka i obywatela z kluczową rolą zasad niepodzielności i laickości republiki. Zdanie de Gaulle'a wypowiedziane na placu Republiki we wrześniu 1958 roku, tuż przed referendum zatwierdzającym konstytucję, że Republika jest ,suwerennością narodu, wołaniem o wolność i nadzieją na sprawiedliwość", zawiera jedną z najbardziej znanych formuł określających francuskie pojmowanie republiki. Powtórzył ją Philippe Séguin w głośnym wystapieniu podczas debaty nad traktatem z Maastricht. Przypominał, że Republika ma we francuskiej tradycji politycznej sens szczególny, nie jest jedynie „rodzajem systemu instytucjonalnego”, lecz jest systemem wspólnych wartości ukształtowanym przez dziedzictwo Rewolucji. Istnieje Republika francuska, jak kiedyś istniała Republika rzymska ${ }^{5}$.

W tym kontekście lepiej zrozumiemy wypowiedź znakomitego historyka francuskiego, że republika w rozumieniu francuskiej tradycji intelektualnej uformowała się w pełni w ostatnich dwóch dekadach XIX wieku, gdy Rewolucja „dopłynęła do portu” i została zinstytucjonalizowana. „Dopiero zwycięstwo republikanów nad monarchistami w początkowym okresie istnienia III Republiki ostatecznie poświadcza zwycięstwo Rewolucji w całym kraju; nauczyciel Jules Ferry, misjonarz zasad roku 1789, bardziej aniżeli instrumentem, jest symbolem tej długiej wygranej batalii" - stwierdza François Furet w eseju Prawdziwy koniec Rewolucji Francuskiej ${ }^{6}$. Republika została definitywnie ukształtowana $\mathrm{z}$ chwilą prawnej instytucjonalizacji dziedzictwa Rewolucji Francuskiej. Podstawowe znaczenie miało uchwalenie ustawy uznającej Marsylianke za hymn narodowy (1879), ustanowienie przez Senat 14 lipca świętem narodowym (1880) i dokonana w 1884 roku nowelizacja ustawy konstytucyjnej z 1875 roku o stosunkach między władzami publicznymi, która wykluczyła przywrócenie monarchii ${ }^{7}$. Dwie ostatnie dekady XIX wieku przy-

${ }^{4}$ M. Agulhon, La République, 1880 à nos jours. Histoire de France, Hachete 1990. Podobnie definiuje Republikę Guy Carcasson w komentarzu do Konstytucji V Republiki: idem, La Constitution, Edition du Seuil 2007, s. 40. Zob. też: F. Luchaire, G. Conac (red.), La Constitution de la République Française. Analyses et commentaires, Economica 2008, s. 130-133.

${ }^{5}$ „Republika jest przede wszystkim systemem wspólnych wartości, dzięki którym Francja jest tym, czym jest w oczach świata. Istnieje Republika francuska, jak kiedyś istniała Republika rzymska. Od początku jej hasło jest takie samo: suwerenność ludu, żądanie wolności, nadzieja na sprawiedliwość" (P. Séguin, Oui, nous voulons Europe, mais debout, w: M. Mopin, Les grands débats parlementaires de 1875 à nos jours, La Documentation Française 1988, s. 311-321.

${ }^{6}$ F. Furet, Prawdziwy koniec Rewolucji Francuskiej, Wydawnictwo Znak 1994, s. 10.

${ }^{7}$ Bardzo interesującą analizę debaty nad nowelizacją ustaw konstytucyjnych z roku 1884 i znaczenia prawnego wykluczenia powrotu do monarchicznej formy rządu znajdziemy w tekście Nathalie Droin, Retour sur la loi constitutionnelle, R.F.D.C. nr 80/ 2009. 
noszą także budowę państwowego i laickiego systemu oświaty. Ostatnim etapem procesu instytucjonalizacji Rewolucji było wprowadzenie radykalnego rozdziału Kościoła od państwa ${ }^{8}$.

W przypadku Francji Republika jest państwem obywateli identyfikującym się z dziedzictwem Rewolucji Francuskiej. Oznacza to nadanie nowego początku francuskiej państwowości, czego wyrazem jest brak jakichkolwiek odniesień w republikańskich konstytucjach do dorobku państwowego sprzed Rewolucji. Naród nie jest ujmowany jako wspólnota ukształtowana przez historię i kulturę jak to ma miejsce choćby w niemieckiej i polskiej tradycji konstytucyjnej, lecz ma charakter wspólnoty politycznej zjednoczonej wokół dziedzictwa Rewolucji. To z tego powodu Philippe Séguin mówił, że „pojęcie narodu jest silniejsze od pojęcia Ojczyzny"9. Tłumaczy to otwarcie Republiki na ludzi ukształtowanych poza kulturą francuską i akceptujących dziedzictwo Rewolucji oraz otwarty sens obywatelstwa opartego na prawie ziemi ${ }^{10}$.

Republika ukształtowała także nowe znaczenie patriotyzmu jako aktu niezgody ludu na podbój Francji, połączonego z identyfikacją z wartościami republikańskimi. „Gdybyśmy mieli wskazać dzień jej narodzin, to byłbym raczej za Valmy, gdy lud chwyci za broń niż za Konwencją następnego dnia, gdy deputowani podjęli decyzję o obaleniu monarchii" - mówił Philippe Séguin, we wspomnianym już wystapieniu ${ }^{11}$. Gdy Comité Général d'Études powołany przez Résistance rozpisał ankietę wśród działaczy Ruchu Oporu, niemal we wszystkich odpowiedziach republikanizm był wiązany z patriotyzmem. Anonimowy historyk biorący udział w ankiecie mówił:

„Republika jawi się Francuzom jako ustrój wszystkich ludzi, jest wielką ideą która we wszystkich sprawach narodowych wzmagała uczucia narodu. To ona w 1793 odegnała grożącą inwazję, to ona w 1870 roku ożywiła francuskie uczucia przeciwko wrogowi, to ona w latach 1914-1918 potrafiła przez cztery lata, w czasie najgorszych prób, utrzymać francuską jedność, jej blaski są blaskami naszego narodu, jej porażki są naszym bólem"12.

Trzeba też zauważyć, że Republika ukształtowana przez dziedzictwo Rewolucji Francuskiej jest też bardziej państwem narodu niż wspólnotą obywateli

${ }^{8}$ Zagadnienie laicyzacji Francji ma bogatą literaturę naukową. Można wskazać najważniejsze prace: P. Barbal, La laicité selon Jules Ferry, Projet 1981; E. Poulat, Liberté, laicité, la guerre des deux France et principe de modernité, Le Cerf-Cujas 1987; R. Rémond, L'anticléricalisme en France, de 1815 à nos jours, Complexe 1985.

${ }^{9}$ P. Séguin, Oui, nous voulons Europe, mais debout, w: M. Mopin, Les grands débats parlementaires de 1875 à nos jours, La Documentation Française 1988, s. 311-321.

${ }^{10}$ Ibidem.

${ }^{11}$ Ibidem.

${ }^{12} \mathrm{H}$. Michel, B. Mirkine-Guetzévitch, Les idées politiques et sociales de la Résistance, Presses Universitaires de France, Paris 1954, s. 46-48. 
w duchu tradycji republikańskiej idącej od Cycerona. W tradycji cycerońskiej „republika jest rzeczą ludu”, a „lud to bynajmniej nie każde zbiorowisko ludzi skupione dowolnym sposobem, lecz wielka ich gromada, zespolona przez uznanie tego samego prawa i przez pożytek płynący ze wspólnego bytowania"13. Tymczasem w przypadku republiki francuskiej zasadnicze nie jest istnienie żywej wspólnoty obywateli wokół prawa i wartości, lecz fakt, że naród posiada państwo zbudowane na wartościach ukształtowanych przez dziedzictwo Rewolucji. To dlatego Gérard Baudson twierdzi, że szczególnie we Francji koncepcja państwa-narodu jest tworem ,,woluntarystycznym i politycznym”. „Kontrakt polega zatem na ustanowieniu państwa, dlatego «uciekanie się do państwa» jest czymś najistotniejszym. Jeśli Państwo-Naród zniknie, kontrakt społeczny między obywatelami zostanie zerwany" "14. Wydaje się, że izolacja de Gaulle'a i Résistance w społeczeństwie francuskim brała się w niemałym stopniu z braku tradycji aktywności narodowej poza strukturami państwa.

Podstawowe znaczenie we francuskiej tradycji republikańskiej mają ukształtowane pod wpływem Rousseau pojęcia suwerenności narodu i volonté générale obecne w Deklaracji praw człowieka i obywatela (art. III i VI Deklaracji). W pierwszej kolejności należy wskazać radykalizm przeniesienia suwerenności z władzy królewskiej na naród. Wprowadzenie tej zasady wywołało radykalne skutki, skoro nawet formalnie monarchistyczna konstytucja z 1791 roku zakwestionowała suwerenność królewską. Michel Morabito w książce poświęconej francuskiemu konstytucjonalizmowi wyraził pogląd, że konstytucja z 1791 roku zgodnie z ideałami 1789 roku zakwestionowała suwerenność królewską, przyznając królowi status przedstawiciela narodu. Monarcha sprawował władzę wykonawczą i uczestniczył w sprawowaniu władzy legislacyjnej, nie miał jednak żadnego udziału we władzy konstytucyjnej. Ta należała wyłącznie do reprezentującego naród ciała ustawodawczego ${ }^{15}$. Podobnie profesor Adam Piasecki w pracy o parlamentaryzmie III Republiki stwierdzał:

„We Francji przeniesienie suwerenności z króla na naród miało charakter rewolucyjny. Konstytucja uchwalona przez to Zgromadzenie, opatrzona deklaracją praw człowieka, jest wyrazem teorii o suwerenności narodu zastosowanej do monarchii dziedzicznej"16.

Wskażmy zatem różnicę między amerykańskim a francuskim doświadczeniem rewolucyjnym. W pierwszej fazie rewolucji amerykańskiej, jeszcze przed uchwaleniem konstytucji Unii, bill of right stanów Wirginii, Maryland

\footnotetext{
${ }^{13}$ B. Szlachta, D. Pietrzyk-Reeves, op. cit., s. 1085.

${ }^{14} \mathrm{G}$. Baudson, L'Europe des apartrides, Lujnes 1994, s. 39.

${ }^{15}$ M. Morabito, D. Bourmaud, Historia konstytucyjna i polityczna Francji (1789-1958), Temi-
} da 2, 1996, s. 46.

${ }^{16}$ A. Piasecki, O parlamentaryzmie III Republiki, Fiszer i Majewski 1928, s. 65. 
i Massachusetts wyrażały prawo narodu do brania udziału w stanowieniu prawa lub zakaz działania bez zgody przedstawicielstwa narodu ${ }^{17}$, gdy tymczasem francuska deklaracja całkowicie kwestionowała udział monarchii (negacja suwerenności królewskiej) i stanów pośrednich w suwerenności uznawszy, że władza suwerenna przysługuje wyłącznie narodowi.

\section{Wyłączenie monarchy z obszaru suwerenności już w pierwszej fazie Re-} wolucji Francuskiej nie jest jedynym specyficznym rysem francuskiego pojmowania suwerenności ludu. Istotniejsze jest to, że idea suwerenności narodu ukształtowała się pod wpływem myśli Rousseau i została zespolona z koncepcją woli powszechnej. Wedle określenia wybitnego prawnika niemieckiego Georga Jellinka w myśli autora Umowy społecznej volonté générale, która „sama decyduje o swoich granicach i której żadna władza ograniczać nie powinna i nie może"18, ma charakter absolutystyczny. W Deklaracji praw człowieka i obywatela z 1789 roku suwerenność przysługuje jedynie narodowi jako całości na zasadzie całkowitego scedowania przez jednostki swych praw na naród-suwerena ${ }^{19}$. Raymond Carré de Malberg w tekście Rozważania teoretyczne w kwestii zwiazku referendum i parlamentaryzmu zintegrował oba pojęcia i pisał o „suwerenności woli ogółu”, wskazując również na jej absolutyzm $^{20}$. Podobnie dla Jacques'a Maritaina mit woli powszechnej służył przeniesieniu „oddzielnej i transcendentnej władzy króla” na lud, który również posiadł władzę oddzielną, transcendentną i absolutną ${ }^{21}$.

${ }^{17}$ Porównanie bill of right $\mathrm{w}$ konstytucjach poszczególnych stanów z francuską Deklaracją praw człowieka i obywatela znajdziemy w pracy G. Jellinka, Deklaracja praw człowieka i obywatela, przeł. Z. Libkund-Lubodzicka, Księgarnia Powszechna 1905, s. 31-44.

${ }^{18}$ G. Jellinek, Deklaracja praw czlowieka i obywatela, op. cit., s. 8-19.

${ }^{19} \mathrm{~W}$ świetnie napisanym szkicu Georg Jellinek wyraził pogląd, że inspirująca Deklarację umowa społeczna Rousseau zawiera tylko jedną klauzulę, mianowicie zrzeczenia się wszelkich praw jednostki na korzyść społeczeństwa. „Jednostka nie zachowuje dla siebie ani atomu prawa, z chwilą gdy staje się członkiem społeczeństwa. Wszelkie prawo otrzymuje od volonté générale, która sama decyduje o swoich granicach i której prawnie ograniczać żadna władza nie powinna i nie może. Nawet prawo własności przysługuje oddzielnej osobie tylko dzięki koncesji państwowej" (G. Jellinek, Deklaracja praw człowieka i obywatela, op. cit, s. 18-19. W podobnym duchu interpretuje myśl Rousseau Dorota Pietrzyk-Revees, wskazując jej kolektywistyczny charakter (tejże, Republikańska koncepcja umowy społecznej, w: Z. Rau, M. Chmieliński (red.), Umowa społeczna i jej krytycy w myśli politycznej i prawnej, Scholar 2010. Warto wspomnieć również o interpretacji Davida Bouchera, który potwierdza absolutystyczny charakter pojęcia woli powszechnej: „Wola powszechna stanowi coś więcej niż sumę wól jednostkowych (sic!), ponieważ jest odbiciem dobra powszechnego, a nie interesu poszczególnych grup. Sprzeciwienie się woli powszechnej jest sprzeciwieniem się własnej woli rzeczywistej" - twierdzi David Boucher, jeden z interpretatorów myśli Rousseau (idem, Rousseau, w: Myśliciele wspótcześni, Wydawnictwo Uniwersytetu Jagiellońskiego 2003, s. 327).

${ }^{20} \mathrm{R}$. Carré de Malberg, Rozważania teoretyczne na temat zwiazku między referendum a systemem parlamentarnym, w: K.M. Ujazdowski, V Republika Francuska. Idee, Konstytucja, Interpretacje", OMP 2010, s. 120-139.

${ }^{21}$ „Mit woli powszechnej - która bynajmniej nie jest po prostu wolą większości, ale monadycznie nadrzedną, niepodzielną wolą emanującą z ludu jako twór jednostkowy, wolą która «zawsze 
Etatyzm i centralizm znalazły zatem mocne oparcie w tak rozumianej idei suwerenności narodu. W miejsce monarchii administracyjnej pojawia się republika niepodzielna, unitarna i scentralizowana. W pracach Tocqueville'a znajdziemy wnikliwy opis ciagłości centralizacji administracyjnej od czasów schyłku monarchii aż po połowę XIX wieku ${ }^{22}$. Również Jacques Maritain we wspomnianym tekście dostrzegał $\mathrm{w}$ tej sferze ciągłość między monarchią a republika, albowiem oba modele ustrojowe nie tolerowały w państwie uprawnień społeczności cząstkowych ${ }^{23}$.

François Furet i Michel Morabito wskazywali, że odrzucenie historycznych i bardziej złożonych teorii legitymizacyjnych przez Deklarację praw człowieka i obywatela z 1789 roku musiało przynieść skutek w postaci centralizacji i odmowy przyznania korporacjom praw publiczno-państwowych. François Furet pisał o odrzuceniu w momencie kryzysu monarchii koncepcji legitymizacyjnej, najmocniej wyrażonej w twórczości Henri Boulainvilliers’a, który podkreślał prawa stanów pośrednich jako trzeciego obok króla i narodu partnera umowy tworzącej Francję ${ }^{24}$. Morabito zaś wspominał o koncepcji ustrojowej Mably’ego, który uznając naród za złożoną wspólnotę stanów, kładł nacisk na „odrębną reprezentację różnych stanów społeczeństwa w łonie organu władzy prawodawczej" 25 . Idea suwerenności narodu i związana z nią zasada

jest słuszna» - był tylko środkiem, za pomocą którego oddzielona i transcendentna władza króla została przeniesiona na lud, będąc nadal oddzielną i transcendentną, w ten sposób, że dzięki mistycznemu działaniu woli powszechnej lud, stając się jednostkowym suwerenem, posiadłby oddzielną, absolutną i transcendentną władzę, odgórną władzę nad sobą jako zbiorowiskiem jednostek" (J. Maritain, Człowiek i państwo, przeł. A. Grobler, Wydawnictwo Znak 1993, s. 52. Identyczny pogląd Maritain zawarł w innej pracy, poświęconej myśli Lutra, Kartezjusza i Rousseau. Francuski filozof stwierdzał, że: „W rzeczywistości nie jest to pakt jakikolwiek, posiada on naturę określoną, zawiera w istocie swej pewne klauzule, bez których byłby niczym - z nich to właśnie Jan Jakub wyprowadzi cały swój system. Oczywiście wszystkie te klauzule sprowadzają się do jednej, a minowicie do całkowitego unicestwienia każdego wspólnika wraz z jego prawami wobec grupy społecznej" (idem, Trzej reformatorzy, Verbum 1938, s. 137).

22 „Rewolucja opowiedziała się jednocześnie przeciw monarchii i przeciw instytucjom prowincjonalnym. Kierowana ślepą nienawiścią niszczyła wszystko, co było przed nią, zarówno władzę absolutnąjak i to, co mogło łagodzić jej siłę. Rewolucja była jednocześnie republikańska i centralistyczna" (A. de Tocqueville, O demokracji w Ameryce, t. I, przeł. H. Szumańska-Grossowa, Społeczny Instytut Wydawniczy Znak 1996, s. 97). Opis rozbudowy administracji kosztem swobód lokalnych i ciał pośredniczących znajdziemy również w znakomitym studium Dawny ustrój i Rewolucja, drugim z najbardziej znanych dzieł Tocqueville'a (Społeczny Instytut Wydawniczy Znak 1994, s. 62-101).

${ }^{23}$ „Skutkiem przedstawionych przez Rousseau zasad i utrwalania się myśli o nieskomplikowanym przeniesieniu na lud transcendentnej najwyższej królewskiej niezależności i władzy, przez co indywidualna wola utraciła wszelką niezależność na rzecz niepodzielnej woli powszechnej, uważano w czasach Rewolucji Francuskiej za oczywistą zasadę, że Suwerenność ludu - absolutna, monadyczna i transcendentna, jak każda suwerenność - wyklucza w państwie możliwość posiadania jakiegokolwiek rodzaju autonomii przez poszczególne zespoły czy organizacje obywateli. Ważne jest, aby nie było w państwie społeczności cząstkowych" (J. Maritain, Człowiek i państwo, op. cit., s. 54).

${ }^{24}$ F. Furet, Prawdziwy koniec Rewolucji Francuskiej, op. cit., s. 45.

${ }^{25}$ M. Morabito, D. Bourmaud, Historia konstytucyjna i polityczna Francji (1789-1958), op. cit., s. 46. 
niepodzielności ma również w czasach współczesnych sens etatystyczny i centralistyczny. Warto odnotować, że Francois Luchaire i Gérard Conac w swoim obszernym komentarzu do konstytucji V Republiki wskazują jej liczne konsekwencje. Niepodzielność republiki pociaga za sobą unitarny charakter państwa, skupienie całości władzy normatywnej w centralnych organach państwa, zakaz przyznawania wspólnotom lokalnym władzy prawodawczej i kompetencji w sferze relacji międzynarodowych oraz rozległe kompetencje kontrolne administracji rządowej nad samorządem. Autorzy zwracają uwagę na to, że głosowanie w wyborach do Parlamentu Europejskiego nie wyraża suwerenności ani nie deleguje jej na instytucje, które byłyby nie do pogodzenia z zasada niepodzielności Republiki. Uważają również, że następstwem tej zasady jest niepodzielność ludu francuskiego, co oznacza zakaz przyznawania mniejszościom językowym, religijnym i etnicznym jakichkolwiek praw zbiorowych ${ }^{26}$.

Trzeba przypomnieć, że zasady ustrojowe Rewolucji Francuskiej były wymierzone przeciw prawom zrzeszeń i korporacji. W wersji skrajnej oznaczało to zakaz konstytuowania się wszelkich zrzeszeń. „Skoro zniweczenie wszystkich odmian związków obywateli tego samego stanu i zawodu jest jedną z fundamentalnych podstaw Konstytucji - zabrania się przywracać je faktycznie pod jakimkolwiek pozorem o w jakiejkolwiek formie"27 - stwierdzały regulacje le loi Chapelier uchwalonego w 1791 roku. Ustawa zakazywała wszelkich zrzeszeń „obywateli tego samego stanu i zawodu”, wprowadzała kary za organizowanie tego typu związków i zakazywała administracji przyjmowania jakichkolwiek adresów i petycji „ułożonych w imieniu stanu lub zawodu”28. Parlament był przekonany, że egzekwuje zasady konstytucji francuskiej uznającej wyłącznie prawa jednostki i całego ludu. Prawa zrzeszeń uznawał za zagrożenie dla wolności potwierdzonych w Deklaracji praw człowieka i obywatela. Zauważmy, że rzecznicy praw korporacji zawodowych i gospodarczych musieli podjać polemikę z zasadami republikańskimi. René Tour du Pin, prekursor korporacjonistyczych rozwiązań ustrojowych, poddawał krytyce Deklaracje praw człowieka i obywatela. W jego opinii Deklaracja inspirowała liberalizm i socjalizm i odmawiała praw zrzeszeniom, uznając tylko jednostkę i naród ${ }^{29}$.

Republika zachowała rezerwę wobec praw zrzeszeń i korporacji, także po uchyleniu drastycznej ustawy Chapelier. Francuski model ustrojowy nie do-

${ }^{26}$ F. Luchaire, G. Conac (red.), La Constitution de la République Française. Analyses et commentaires, Economica 2008, s. 133-139.

${ }^{27}$ Ustawa Le Chapelier z 14 czerwca 1791 r. (w przekładzie Teresy Janasz). Cyt. za: M.J. Ptak, M. Kinstler, Powszechna historia państwa i prawa, Wydawnictwo Uniwersytetu Wrocławskiego 1999 , s. 65

${ }^{28}$ Ibidem.

${ }^{29} \mathrm{Na}$ ten aspekt myśli René du Tour du Pina zwrócił uwagę Czesław Strzeszewski w syntezie katolickiej nauki społecznej: idem, Katolicka nauka społeczna, ODISS 1985, s. 241-242. 
puszcza do przekazywania korporacjom zawodowym i gospodarczym uprawnień publicznych, tak jak dzieje się to w wielu krajach europejskich ${ }^{30}$. Reprezentacja interesów gospodarczych jest realizowana wyłącznie wewnątrz struktur państwowych, co tłumaczy specyfikę obowiązującego do dziś silnie zetatyzowanego modelu kapitalizmu francuskiego. W latach trzydziestych XX wieku sposób wyrażania opinii o projektach ustaw gospodarczych przybrał instytucjonalny wyraz w postaci Rady Ekonomicznej. W pierwszej fazie Rada działała na podstawie dekretu prezydenta ze stycznia 1925 roku, później ustawy z 1926 roku, w IV Republice zaś stała się instytucją konstytucyjną. Bardzo charakterystyczne, że w instytucji tej Konstanty Grzybowski widział, podobnie jak w Radzie Stanu, ciało pośredniczące, limitujące władzę ${ }^{31}$. W braku realnych ciał społecznych niezależnych od struktur administracyjnych rola korygowania władzy politycznej miała przypaść instytucjom państwowym cieszącym się autonomią, takim jak Rada Stanu czy Rada Ekonomiczna. Ta ostatnia ukształtowała się jako instytucja doradcza i rozwiązująca konflikty na mocy praw arbitrażowych. Bardzo wymowne jest to, że nie zdecydowano się na przyznanie jej prawa do współkształtowania umów zbiorowych, w czym widziano niebezpieczeństwo korporacjonizmu poza kontrolą państwa ${ }^{32}$.

Idea suwerenności narodu - czy wedle określenia Carré de Malberga ,suwerenności woli ogółu" - okazała się najważniejszym elementem ciągłości republikańskiego porządku ustrojowego, legitymacji władzy i prawa (ustawa jako wyraz volonté générale). We wnikliwej pracy poświęconej III Republice Adam Piasecki podkreślał, że „,pojęcie suwerenności narodowej zaczerpnięte z filozofii Rousseau stanowiło podstawę ideową wszystkich konstytucji republikańskich Francji" ${ }^{33}$. Wolno sądzić, że była ona nawet podstawą wszystkich porewolucyjnych konstytucji z wyjątkiem dwóch okresów: Restauracji w la-

${ }^{30}$ Jadwiga Staniszkis uważa, że ten model kapitalizmu utrzymywał się we Francji aż do czasów współczesnych i że należy go analizować pod kątem ekonomii politycznej, a nie ekonomii czystej (eadem, Postkomunizm, Słowo/ obraz terytoria 2001, s. 219.

${ }^{31}$ K. Grzybowski, Demokracja francuska, Czytelnik 1947, s. 105, 106.

32 „Miała ona być z jednej strony arbitrem w sprawach konfliktów gospodarczych i społecznych i współdziałać w ustalaniu treści umów zbiorowych-z drugiej strony miała być organem doradczym rządu i parlamentu. Ten pierwszy zamiar nie znalazł oparcia w Izbach, widziano w nim otwarcie drogi ku ustrojowi korporacyjnemu, a więc ku usunięciu politycznego parlamentu na dalszy plan", K. Grzybowski, Demokracja francuska.., s. 106.

Interesujące uwagi na temat ciał korporacyjnych zawarł Marc Bloch w Rachunku sumienia Francuza. W opini znakomitego historyka ciała te miały pozycję silniejszą niż parlament i ministrowie. „A czy nasze parlamenty i ministrowie istotnie tak bardzo rządzili? Zachowali pozostałe po poprzednich systemach liczne oficjalne ciała, nad którymi bynajmniej nie sprawowali ścisłego nadzoru", M. Bloch, Rachunek sumienia Francuza, w: M. Bloch, Dziwna klęska, Oficyna Naukowa 2008, s. 246.

${ }^{33}$ „W poglądach politycznych francuskich pojęcie suwerenności narodu jest głęboko zakorzenione, a także zagadnienie suwerenności jest przedmiotem żywej dyskusji kół prawniczych. Inaczej jest w Anglii. Władza suwerena dynastii angielskiej przeszła stopniowo w pełni na naród angielski, ale stało się to prawie niepostrzeżenie. Dziś król dzieli władzę z organami powstałymi z wyboru, 
tach 1815-1830 i Vichy. Zasadniczej kontrowersji między Republiką a Restauracją, o której pisze Furet, nie należy traktować jako formuły publicystycznej, oddaje bowiem dobrze fundamentalną różnicę między tradycją monarchistyczną i republikańską we Francji. Jedynie Karta konstytucyjna z okresu Restauracji, obowiązująca w latach 1815-1830, przywróciła monarchiczne zasady legitymizacyjne i zakwestionowała republikański porządek. Wybitny francuski prawnik Adhemar Esmein, którego oddziaływanie na naukę prawa konstytucyjnego w Europie trudno przecenić, twierdził:

„Najdonioślejszą z zasad wygłoszonych przez Wielką Rewolucję jest zasada zwierzchnictwa narodu. Prócz Karty 1814 uznały ją i przyjęły za podstawę wszystkie tak przecież rozmaite konstytucje francuskie" ${ }^{\text {"34 }}$.

Zasada suwerenności narodu była zatem podstawą ustroju monarchii konstytucyjnej z lat 1789-1792, monarchii lipcowej, konsulatu, I i II Cesarstwa. To prawda, że tradycja republikańska występowała przeciw bonapartyzmowi z jego władzą spersonalizowaną i arbitralną. Trzeba jednak pamiętać, że cesarstwo przyjmowało republikańską aksjologię wraz z odwołaniem się do suwerenności narodu i rozpowszechniło poza granicami Francji dorobek polityczny i prawny Rewolucji.

\section{Patriotyzm państwowy de Gaulle'a.}

1. Formuła V Republiki jako monarchii republikańskiej sugeruje, że de Gaulle doprowadził do aksjologicznej oraz instytucjonalnej syntezy obu tradycji. W podobnym duchu François Mauriac pisał w Bloc-notes, że de Gaulle położył kres kontrowersji między nacjonalistyczną i monarchistyczną Action Française a chrześcijańsko-demokratycznym i wyraźnie prorepublikańskim Sillon Marka Sangiera ${ }^{35}$. Wydaje się, że obie interpretacje nie wyjaśniają dobrze ani kształtowania się poglądów de Gaulle’a, ani genezy i specyfiki V Republiki.

a właściwie tonie we władzy parlamentu, będąc uważanym za jeden z jego składników" (A. Piasecki, O parlamentaryzmie III Republiki, Fiszer i Majewski 1928, s. 64-65).

${ }^{34}$ A. Esmein, Prawo konstytucyjne, Księgarnia Hoesicka 1921, s. 211.

35 ,Jeden z wielkich oddanych mu ludzi, będący mniej więcej jego rówieśnikiem (moim także), powiedział mi kiedyś słusznie: «Tylko katolicy naszego pokolenia są zdolni pojąć kim jest de Gaulle, gdyż przejął on zarazem dziedzictwo Sillon i Action Française. Czerpał z obydwu antagonistycznych źródeł i pojednał je w sobie, ale dlatego też jest zawsze samotny»" (F. Mauriac, Bloc-notes, przeł. Z. Milewska, PAX 1979, s. 137). Warto dodać, że sam Mauriac znajdował się krótko pod wpływem ruchu Sillon i jego charyzmatycznego przywódcy. Współpraca i rozejście się pisarza z ruchem Sillon stały się tematem jego debiutanckiej powieści pt. Ciężkie okowy dzieciństwa (PAX 1985). Warto przypomnieć, że żywo zainteresowany literaturą de Gaulle cenił pisarstwo Mauriaca, a pisarz w tekstach publicystycznych wspierał działania polityczne przywódcy Wolnych Francuzów. W 1964 roku Mauriac opublikował książkę poświęconą de Gaulle’owi (De Gaulle, Grasset). Syn pisarza, Claude Mauriac, był sekretarzem de Gaulle’a po wyzwoleniu Francji w 1944 roku i podobnie jak ojciec poświęcił mu książkę (Aimer de Daulle, Paris 1978). 
De Gaulle wychował się w rodzinie silnie ukształtowanej przez chrześcijaństwo, gorliwie patriotycznej i przywiązanej do tradycji monarchistycznej. Jean-Raymond Tournoux tak przedstawiał monarchizm rodziców przyszłego generała oraz ich sprzeciw wobec dziedzictwa Rewolucji:

„Pod koniec XIX wieku w oczach ojca i matki Charles'a de Gaulle'a - którzy byli kuzynami, potomkami stryjecznych braci - republika jawiła się na kształt kobiety-uzurpatora bez odrobiny rozumu. W owych czasach to uczucie było rozpowszechnione zarówno wśród arystokracji, jak i wśród mieszczaństwa, a nawet częściowo wśród ludu, zwłaszcza na wsi. Atmosfera panująca w kręgu rodzinnym de Gaulle’a nie była zatem wyjątkowa ani szokująca"36.

Trzeba bowiem podkreślić, że III Republika nie była aż do kresu swojego istnienia przedmiotem konsensusu, jej uformowanie odbyło się kosztem jedności narodowej. Jean-Louis Quermonne pisał, że pomimo wezwania ze strony Stolicy Apostolskiej do uznania republiki w encyklice Leona XIII Au milieu des Solicitudes ${ }^{37}$ konsensus wokół niej istniał tylko w czasie „Union sacre”, która złączyła Francuzów w latach I wojny światowej ${ }^{38}$. Od lat osiemdziesiątych XIX wieku aż do klęski Francji w 1940 roku III Republika była przedmiotem ostrej krytyki z umotywowanymi stanowiskami doktrynalnymi i silnymi wpływami społecznymi. Istotna część społeczeństwa francuskiego zachowała wierność tradycji monarchistycznej i sprzeciwiała się radykalnej laicyzacji skutkującej usunięciem Kościoła z życia publicznego i społecznego. Rozdarcie Francji znalazło wyraz w klasycznych dziełach literatury francuskiej, trzeba wymienić w tym kontekście przede wszystkim powieści Anatole'a France'a i Roger Martin du Garda ${ }^{39}$.

Powstanie nacjonalistycznej i rojalistycznej Action Française w roku 1899 nadało tej tendencji nową dynamikę, prestiż i wpływy w środowiskach intelektu$\operatorname{alnych}^{40}$. Charles Maurras związał nacjonalizm z monarchizmem, tworząc nowe

${ }^{36}$ J.-R. Tournoux, Po raz pierwszy ujawnione, przeł. A. Galica, Książka i Wiedza 1971, s. 18.

${ }^{37}$ Interesującą analizę katolicyzmu francuskiego tamtej epoki oraz racji, dla których Leon XIII wydał encyklikę Au milieu des Solicitudes i zachęcił do uznania porządku republikańskiego, znajdziemy w tekście Rogera Auberta, Kościót katolicki od kryzysu 1848 do pierwszej wojny światowej, w: Historia Kościoła, t. V, PAX 1985. Trzeba zwrócić uwagę na opracowanie C. Brice, Essai d'une politique chrétienne en Europe jusqu'en 1914, w: P. Ory (red.), Nouvelle histoire des idées politiques, Hachette 1987.

${ }^{38}$ J.-L. Quermonne, République, w: O. Duhamel, Y. Mény, Dictionnaire constitutionnel, Presses Universitaires de France 1992, s. 922.

${ }^{39}$ Trzeba wskazać czterotomowy cykl powieściowy Anatola France’a Historia wspótczesna (Książka i Wiedza 1949) oraz Rodzinę Thibault Rogera Martin du Garda (Czytelnik 1987). W tym samym kontekście warto przywołać książkę współczesnego pisarza francuskiego Le Clezio Powracajacy głód (WAB 2009).

${ }^{40}$ Wypada wskazać najnowsze opracowania poświęcone Action Française w literaturze polskiej: J. Bartyzel, Umierać, ale powoli. O monarchistycznej i katolickiej kontrrewolucji w krajach ro- 
uzasadnienie dla monarchii: „Monarchia jest we Francji konstytucją naturalną i rozumna, jedyną możliwą konstytucją władzy centralnej. Bez króla wszystko, co chcą konserwować nacjonaliści, musi ulec nieuchronnemu osłabieniu, a w końcu zniszczeniu" - twierdził Maurras w Autobiografii filozoficznej ${ }^{41}$.

W doktrynie Action Française republika była tworem obcym, narzuconym Francji przez ludzi, którzy odnosili się wrogo do jej wielowiekowego dziedzictwa historycznego. Twórca nacjonalizmu integralnego pisał o czterech stanach niszczących Francję: Żydach, protestanatach, masonach i cudzoziemcach. „Trzecia Republika jest anarchią usystematyzowana, regulowaną i eksploatowaną przez czynniki zewnętrzne, które same w sobie i dla siebie nie są anarchiczne" ${ }^{42}$. Republika ze względu na swą naturę marginalizowała interes państwa, to, co partykularne brało górę nad tym, co wspólne. „Republikę można zdefiniować jako dominację interesów, uczuć i woli partii politycznych nad interesem narodowym w aspekcie warunków międzynarodowych" ${ }^{33}$. A więc republika francuska była ustrojem „,bez głowy”, pozbawionym czynnika stałego. Z punktu widzenia szkoły Maurrasa zerwanie z republiką i rekonstrukcja monarchii stanowiły zatem zasadniczy warunek odbudowy siły Francji.

W opinii historyków, m.in. Aleksandra Halla i Erica Roussela - autorów nowych biografii generała - jego ojciec, Henri de Gaulle, ceniony nauczyciel i wychowawca wielu pokoleń uczniów, miał sympatię do Action Française, choć w sprawie Dreyfusa zachował sąd niezależny od Charles'a Maurrasa, nie wierząc we współpracę oficera $\mathrm{z}$ wywiadem niemieckim ${ }^{44}$. Wiele wskazuje na to, że był raczej monarchistą w wydaniu legitymistycznym i zachowywał krytyczny stosunek do idei i praktyki politycznej Action Française ${ }^{45}$. Wskazują na to wspomnienia Philippe'a de Gaulle'a ${ }^{46}$. W każdym razie Henri de Gaulle miał jednoznacznie krytyczną opinię o porządku republikańskim. Warto przy-

mańskich 1985-2000, Arcana 2002; A. Wielomski, Nacjonalizm a konserwatyzm w myśli Ch. Maurrasa, w: J. Bartyzel, D. Góra-Szopiński (red.), Nacjonalizm a konserwatyzm i monarchizm. Action Française i jej promieniowanie, Wydawnictwo Adam Marszałek 2011, s. 84-110.

${ }^{41} \mathrm{Ch}$. Maurras, Credo. Autobiografia filozoficzna, przeł. J. Bartyzel, w: J. Bartyzel, D. Góra-Szopiński, Nacjonalizm a konserwatyzm i monarchizm, op. cit., s. 49.

${ }^{42}$ Ch. Maurras, La démocratie religieuse, 1921, s. 329.

${ }^{43}$ Ch. Maurras, Enquête sur la Monarchie, 1924, cyt. za: J. Bartyzel, Umierać, ale powoli, op. cit., s. 576.

${ }^{44}$ A. Hall, Naród i państwo w myśli politycznej Charles'a de Gaulle’a, Neriton 2005, s. 28. E. Roussel, powołując się na opinię Edouarda Bonnefous, ucznia Henri de Gaulle'a i ministra stanu w okresie IV Republiki, pisał o jego gorącej pobożności i dramacie, jaki przeżywał po ekskomunice Action Française. Po decyzji Stolicy Apostolskiej Henri de Gaulle zaniechał lektury dziennika wydawanego przez Maurrasa (E. Roussel, De Gaulle I. 1980-1945, Perrin 2002, s. 23, 24).

${ }^{45}$ Krytykę szkoły Action Française przeprowadzoną z pozycji legitymistycznych wnikliwie omówił J. Bartyzel w artykule Neorojalizm nacjonalistyczny Action Française w świetle zasad legitymizu monarchicznego, w: J. Bartyzel, D. Góra-Szopiński, Nacjonalizm a konserwatyzm i monarchizm, op. cit.

${ }^{46} \mathrm{Ph}$. de Gaulle, De Gaulle mój ojciec, t. I, przeł. E. Derelkowska, Z. Domański, Zysk i S-ka 2008, s. 397. 
pomnieć, że w proteście przeciwko ustawom z 1884 roku zrezygnował z pracy W ministerstwie spraw wewnętrznych i od tej pory poświęcił się pracy nauczycielskiej w szkołach katolickich ${ }^{47}$.

Matka generała, Jeanne, była gorliwą katoliczką o wyraźnie monarchistycznych i antyrepublikańskich poglądach. Zachowały się świadectwa jej krytycznej reakcji na to, że synowie zaakceptowali republikę. Philippe de Gaulle wspomina:

„Babka Jeanne była niemal fanatycznie religijna i dobitnie mówiła o swoich poglądach. Przed 1914 rokiem żałowała, że jej synowie, w tym i mój ojciec, zostali republikanami. Jej zdaniem wśród republikanów było zbyt dużo ateistów, niedowiarków i kosmopolitów, którym nie można było ufać, bo nie poczuwali się do francuskich korzeni i nie hołdowali francuskim tradycjom"48.

2. W nowej i niezwykle ciekawej interpretacji kształtowania się poglądów de Gaulle'ów profesor Odile Rudelle wskazuje na duży wpływ „Correspondant", pisma o katolicko-liberalnym i umiarkowanie monarchistycznym profilu abonowanego przez rodzinę przez kilkadziesiąt lat. „Correspondant” jako pismo wyrażające legitymizm konstytucyjny, opowiadało się za równowagą między siłą państwa a wolnością, broniło tradycyjnych wolności, szczególnie wolności religijnej oraz praw szkolnictwa katolickiego. Krytykowało zarówno dyktaturę II Cesarstwa i rządzenie za pomocą plebiscytów, jak i „republikę republikanów"49. W połowie XIX wieku z periodykiem byli związani ludzie, którzy odegrali istotną rolę w kulturze i polityce francuskiej - trzeba wymienić przede wszystkim Alfreda de Falloux (1811-1886) i Charles'a Montalemberta (1818-1870). Pierwszy z nich był historykiem i politykiem o legitymistycznej orientacji. Przeszedł do historii jako autor uchwalonego w 1850 roku prawa dającego przywileje duchownym nauczającym w szkołach powszechnych. Charles Montalembert, publicysta i mąż stanu, próbował godzić katolicyzm z porewolucyjnym porządkiem ustrojowym, również przywiązywał wielką wagę do roli religii w systemie oświaty ${ }^{50}$. Pismo, zachowując sentyment

${ }^{47}$ E. Roussel, De Gaulle I. 1980-1945, Perrin 2002, s. 22.

${ }^{48} \mathrm{Ph}$. de Gaulle, De Gaulle mój ojciec, t. I, op. cit., s. 395. Podobnie E. Roussel, De Gaulle I. 1880-1945, op. cit., s. 23. Podobne opinie można znaleźć można w biografii Yvonne de Gaulle: G. Molle, Y. de Gaulle. Historia i życie, 2004, s. 31-32. „Matka Charles'a, osoba o żarliwym charakterze, nieprzejednana katoliczka, namiętna patriotka, «niemal fanatyczka» - jak wspominają jej dzieci - szlochała na wieść o klęsce pod Sedanem. Już przedtem tonęła w łzach, jakże gorzkich, i boleśnie przeżyła fakt, że hrabia de Chambord uważał za wskazane raczej zrezygnować z tronu, niż uznać trójkolorowy sztandar" (J.R. Tournoux, Po raz pierwszy ujawnione..., op. cit., s. 19).

${ }^{49} \mathrm{O}$. Rudelle, L'Année 1946: les stratégies d'intervention du général de Gaulle, w: La Genèse $d u$ RPF, Fondation Charles de Gaulle 1997, s. 179-199.

${ }^{50}$ Charles Forbes de Tryon de Montalembert (1810-1870), francuski publicysta, mąż stanu. Współpracował z Lamennaism'em i Lamartine'em w wydaniu dziennika « L'Avenir ». W sporze tego pierwszego z papieżem przyjął werdykt potępiający Lamennais'go. Od 1831 roku zasiadał w Iz- 
monarchistyczny, nie było z góry przeciwne republice, sprzyjało jedności społecznej i narodowej oraz wzmocnieniu państwa, zachowując krytycyzm zarówno wobec dyktatur, jak i supremacji parlamentu.

W świetle tradycji „Correspondenta” lepiej można zrozumieć fakt, że Charles de Gaulle mógł, zachowując wysoką ocenę historycznych zasług monarchii, uznać republikę. Tym bardziej że na poglądy samego de Gaulle'a największy wpływ wywarły idee republikańskich nacjonalistów, Maurice'a Barrèsa i Charles'a Péguy, nie zaś monarchizm w wersji legitymistycznej czy też w ujęciu doktryny Action Française.

Maurice Barrès, pisarz i polityk o wielkim oddziaływaniu wychowawczym, był nacjonalistą republikańskim, wzywającym do jedności patriotów o różnych orientacjach ideowych ${ }^{51}$. Wizja narodu głoszona przez tego pisarza i polityka miała organicystyczny i chrześcijański charakter i również z tego względu mogła być bliska de Gaulle’owi. Barrès był uczuciowo związany z dziedzictwem Rewolucji jako nierozłącznym z przeznaczeniem narodowym, przeznaczeniem „Francji we własnej osobie”. Z tego też powodu nie myślał nigdy o podważaniu republikańskiej formy rządu.

bie Parów. Usiłował spoić katolicyzm z francuską formą demokracji. Występował przeciwko monopolowi rządu w dziedzinie wychowania publicznego, był także obrońcą wolności prasy. Głosował przeciw wygnaniu Orleanów i konstytucji 1848. Po wydarzeniach 1848 we Włoszech i wygnaniu z Rzymu Piusa IX stał się gorącym orędownikiem francuskiej interwencji mającej przywrócić panowanie papieża w Państwie Kościelnym. Starł się wówczas m.in. z Wiktorem Hugo. W nagrodę za działalność w tym trudnym dla papiestwa okresie Ojciec Święty przyznał mu obywatelstwo rzymskie (1850). W 1851 roku wybrany do Akademii Francuskiej. Na początku lat 50. XIX w. aktywnie włączył się w sprawy rządowe, wszakże z czasem rozczarował się do polityki Napoleona III. Po przegranej w wyborach 1857 roku wycofał się z życia publicznego. W 1869 roku wystapił przeciw dogmatowi o nieomylności papieskiej. Montalembert był orędownikiem sprawy polskiej na forum międzynarodowym. Wspierał ją wystapieniami publicznymi i artykułami prasowymi. Głośnym echem odbiła się m.in. jego przemowa z 19 III 1846 roku, w której poddał surowej krytyce politykę austriacką wobec Polski, zwłaszcza postawę księcia Metternicha. Po likwidacji Rzeczypospolitej Krakowskiej żądał interwencji rządu francuskiego w tej sprawie. W 1861roku przybył do Krakowa. Ówczesne nastroje w społeczeństwie polskim, zwłaszcza żałoba narodowa po represjach rosyjskich w Królestwie, skłoniły go do napisania kolejnych tekstów w obronie praw Polaków. Przed śmiercią przekazał swe cenne zbiory Bibliotece Polskiej w Paryżu. Montalembert napisał m.in. Histoire de Ste Elisabeth de Hongrie (1836) i Les Moines d'Occident (7 t., 1874-1877). Warto przywołać w tym miejscu poświęcony Montalembertowi artykuł Pawła Popiela Karol Hrabia Montalembert, w: J. Kloczkowski (oprac.), Choroba wieku. Wybór pism, OMP 2001, s. 24-48. Bardzo interesujące uwagi o poglądach Montalemberta odnajdziemy w pracy prof. Marii Zmierczak poświęconej ideologii liberalnej w okresie II Cesarstwa (eadem, Ideologia liberalna w II Cesarstwie, UAM 1978, s. 47). Montalembert był przyjacielem Adama Mickiewicza, thumaczem Ksiag pielgrzymstwa narodu polskiego i gorącym orędownikiem sprawy polskiej na arenie międzynarodowej. Wiele cennych informacji o współpracy Montalemberta z Mickiewiczem i wsparciu dla sprawy polskiej w pracy Marii Czapskiej, Szkice Mickiewiczowskie, Oficyna Wydawnicza Rytm 1999.

${ }^{51}$ Warto w tym kontekście wspomnieć o esejach François Mauriaca poświęconych moralnemu oraz intelektualnemu wpływowi Barrèsa na młodsze pokolenia Francuzów: Spotkanie z Barresem oraz Barrrès, w: idem, Burza cichnie o zmierzchu, PAX 1962. 
W imię zasady ciągłości historii francuskiej odrzucał myśl o usuwaniu jakiegokolwiek etapu z historii Francji ${ }^{52}$. Eric Roussel twierdzi w biografii de Gaulle'a, że w przeciwieństwie do Charles'a Maurrasa, rojalistycznego teoretyka nacjonalizmu integralnego, Barrès nie potępiał żadnego okresu z historii Francji, nawet Rewolucji. Francuski historyk odnajduje wątki barresowskie w zakończeniu Pamiętników wojennych ${ }^{53}$ i przytacza list de Gaulle'a do Jean Louis-Domenacha, autora biografii Barrèsa, potwierdzający inspirację jego myślą ${ }^{54}$. Wypada dodać, że Yvonne i Charles de Gaulle'owie admirowali pisarstwo Barrèsa, w sposób szczególny Colette Badauche, powieść o wymowie patriotycznej i antyniemieckiej ${ }^{55}$.

Charles Péguy, eseista i poeta, przeszedł ewolucję od socjalizmu do żarliwego patriotyzmu i pogłębienia wiary chrześcijańskiej. W czasie afery Dreyfusa opowiadał się za rewizją procesu i występował w obronie pomówionego oficera. W 1900 roku założył pismo „Les Cahiers de la Quinzaine”, w którym publikował teksty o tematyce politycznej i artystycznej. Dzięki Maritainowi przeżył pogłębienie wiary i stał się żarliwym patriotą i chrześcijaninem ${ }^{56}$. Péguy, podobnie jak Barrès, akceptował republikę, wyznawał otwarty, integrujący patriotyzm. Twórczość Péguy przyciagała również ludzi wychowanych poza kręgiem kultury chrześcijańskiej, wśród nich Michela Debré ${ }^{57}$. De

${ }^{52}$ R. Giradet, Barrès, w: F. Chatelet. O. Duhamel, E. Plisier, Dictionnaire des oeuvres politiques, PUF 1986, s. 71-73. Jacek Bartyzel w pracy poświęconej kontrrewolucyjnej prawicy twierdził, że uznanie dla republiki wynikało z tradycjonalizmu Barrès'a: „Według Barresa być dziś tradycjonalistą to znaczy właśnie akceptować Republikę, ponieważ wymaga tego akceptowanie zasady ciagłości... Tradycjonalista, aby nie popaść w konflikt w wymogami społecznego realizmu, musi akceptować rzeczy takimi, jakie są one w konkretnej rzeczywistości, w tym wypadku oznacza to konieczność pogodzenia się z instytucjami republikańskimi, gdyż one są realne, a nie monarchia. Dopóki istniała, stanowiła rzeczywistą inkarnację Francji, budowała dobro wspólne i to jej Francja zawdzięcza swoją chwałę. Ale pracować dla dobra wspólnego to znaczy naprawiać to, co jest, a nie przywracać to, co stanowi najbardziej nawet majestatyczną choćby część narodowego cmentarza" (J. Bartyzel, Umierać, ale powoli, op. cit., s. 475).

${ }^{53}$ Chodzi o końcową partię Pamiętników wojennych, w której de Gaulle wyraził miłość do Ojczyzny powiązaną z umiłowaniem płodnej ziemi: „Stara Ziemia, zorana pługiem czasu, smagana przez deszcze i burze, wycieńczona wegetacją, ale zawsze, do nieskończoności, gotowa wytwarzać wszystko, co jest potrzebne, aby żywi mogli następować po sobie! / Stara Francja, dźwigająca na swych barkach brzemię Historii, umęczona wojnami i rewolucjami, krocząca stale od wielkości do upadku, ale z każdym stuleciem odradzana przez ducha odnowy! / Stary człowiek, sterany trudami życia, oderwany od spraw tego świata, czujący, jak zbliża się już chłód wieczności, ale wciąż wypatrujący w ciemnościach jakiegoś przebłysku nadziei!” (Ch. de Gaulle, Pamiętniki wojenne, t. III, Wydawnictwo MON 1968, s. 294).

${ }^{54}$ E. Roussel, De Gaulle I. 1980-1945, op. cit., s. 35.

${ }^{55}$ „Nie wie jeszcze, że Charles, tak jak i ona, uwielbia Colette Badauche, książkę Maurice'a Barrrčsa. Dla niego jest to historia oporu młodej Lotarynki wobec niemieckiego okupanta, dla niej tragedia dziewczyny, która na przekór miłości pragnie pozostać wierna ojczyźnie i pamięci przodków" (G. Moll, Y. de Gaulle. Historia i życie, op. cit., s. 27).

${ }^{56}$ Y. Avril, Życie i twórczość Charles'a Péguy, w: Charles Péguy. Człowiek dialogu, Akade 2003, s. 22.

${ }^{57}$ S. Armotorio, La pensée politique et constitutionnelle de Michel Debré, L.G.D.J. 2006, s. 20. 
Gaulle był pod wpływem myśli łączącej wiarę i patriotyzm z poczuciem odpowiedzialności społecznej. W myśli Peguy Francja była sumą, całością, miejscem spotkania tradycji antycznej, tradycji chrześcijańskich i tradycji rewolucyjnych. Wedle Jeana Toucharda, autora klasycznej już historii idei politycznych: „Péguy, który czytał Micheleta zintegrował Rewolucję z tradycją francuską. Był przekonany, że Francja ma podwójne powołanie, powołanie chrześcijańskie i powołanie do promocji wolności. Joanna d'Arc symbolizowała jedno i drugie" ${ }^{58}$. Wprowadził rozróżnienie między mistyką, czyli żywotnością idei, a polityka, która niszczy ideały. Mistyka rewolucyjna i chrześcijańska są sobie bliskie, oddala je praktyka polityczna. „Każda partia żyje swoją mistyką i umiera na skutek swej polityki" ${ }^{59}$. Postawę i twórczość Péguy porównywano z dziełem Wyspiańskiego ${ }^{60}$. Poeta dowiódł jedności myśli i czynu, zginął na polu bitwy w 1914 roku. De Gaulle sam złożył świadectwo o przemożnym wpływie twórczości Péguy w okresie swojej młodości i dorastania: „Żaden autor nie miał tak silnego wpływu na moją młodość, jak Péguy, żaden nie inspirował mnie tak w tym, co przedsiębrałem: duch V Republiki możecie znaleźć w »Cahiers de la Quinzaine«" ${ }^{11}$. De Gaulle w pełni identyfikował się z myślą poety w kwestii jedności historii Francji, znakomicie wyrażonej w sławnej formule: „Republika jest niepodzielna, to nasze królestwo Francji”'62.

Wydaje się zatem, że na tym gruncie właśnie z inspiracji Barrèsa i Péguy ukształtował się patriotyzm państwowy de Gaulle'a, akceptujący republikę, przekraczający ostre podziały, inkluzywny w stosunku do różnych tradycji ideowych i zorientowany na wzmocnienie państwa jako narzędzia potęgi Francji. W jego oczach państwo oparte na republikańskich zasadach nie musiało być skazane na słabość, mogło służyć potędze Francji tak, jak służyła tej potędze monarchia w najlepszych okresach swego istnienia. Decydujące znaczenie w procesie kształtowania się poglądów de Gaulle'a miała erudycja historyczna wskazująca, że wielkie dokonania były dziełem zarówno monarchii, jak i republiki. W wydanej w latach trzydziestych książce La France et son armée wskazywał przykłady efektywnej polityki w historii I, II i III Republiki, szczególnie wysoko oceniając dokonania Carnota, Gambetty, Poincaré i Clemenceau ${ }^{63}$.

De Gaulle nie mógł zatem akceptować nacjonalizmu Action Française, całkowicie kwestionującego tradycję republikańską jako szkodliwą dla Fran-

${ }^{58}$ J. Touchard, Histoire des idée politiques, t. 2, s. 695 i bibliografia, s. 712.

${ }^{59}$ Ch. Péguy, Notre jeunnese, w: idem, Les oeuvres en prose, Edition Gallimard 1961, s. 508-521.

${ }^{60}$ E. Krakowski, Des poètes de l' heroisme: Charles Péguy et Stanislaw Wyspiański, Paris 1937.

${ }^{61}$ Roussel dostrzega w londyńskiej wypowiedzi o Notre-Dame de France echa myśli poety (idem, De Gaulle I. 1980-1945, op. cit., s. 35). Trzeba dodać, że również w listach de Gaulle'a do żony Yvonne z podróży po Bliskim Wschodzie znajdziemy odwołania do powieści Barrès'a Un jardin sur l' Oronte (G. Moll, Y. de Gaulle. Historia i życie, op. cit., s. 60.

${ }^{62}$ E. Roussel, De Gaulle I. 1880-1945, op. cit., s. 35.

${ }^{63}$ Ch. de Gaulle, La France et son armée, Plon 1938. 
cji $^{64}$. Ze szkołą Maurrasa mogła go łączyć czujność wobec ekspansji niemieckiej i uznanie dla geopolitycznych analiz Jacques'a Bainville'a, zasadniczo jednak różniła formuła patriotyzmu i stosunek do państwa. A zatem wbrew opinii Mauriaca, de Gaulle nie przyjął dziedzictwa szkoły Action Française i nie był jej kontynuatorem.

3. Nie był też, jak sugeruje znakomity pisarz, spadkobiercą ruchu Sillon. Istotne dla zrozumienia idei i polityki de Gaulle'a inspiracje myślą chrześcijańsko-społeczną wymagają precyzyjnego wyjaśnienia. W poglądach de Gaulle'a nie znajduję wpływu koncepcji twórcy ruchu Sillon, Marca Sangniera, z jego entuzjazmem w stosunku do wartości republikańskich i demokratycznych ${ }^{65}$. Sillon uważał, że wartości te mają chrześcijański rodowód i posuwał się znacznie dalej w uznaniu dla aksjologii republikańskiej niż ci, którzy za wskazaniem Leona XIII wyrażonym w encyklice Au milieu des Solicitudes zdecydowali się na „ralliement”, przyłączenie do Republiki. O ile „ralliement” było po prostu uznaniem możliwości realizacji zadań chrześcijańskich w ramach ustroju republikańskiego, to Marc Sangnier głosił, że jedynie ustrój demokratyczny ze względów etycznych zasługuje na miano systemu prawdziwie chrześcijańskiego.

Sillon w latach 1903-1905, gdy przeprowadzano radykalny rozdział Kościoła od państwa, organizował wiece wspierające porządek republikański. W roku 1910 doktryna Sillon została potępiona przez Stolicę Apostolską w encyklice Notre charge apostolic ${ }^{66}$. Pius X zarzucał Sillon, że utożsamia zadania chrześcijańskie z budową demokratycznego i egalitarnego społeczeństwa. Katolicyzm Sillon zadowala się wyłącznie demokratyczną formą rządu i „podporządkowuje religię orientacji politycznej" ${ }^{67}$. W opinii papieża, ruch Marca Sangniera porzucił katolicki charakter na rzecz wizji nowego uniwersalnego Kościoła i nowego egalitarnego i braterskiego społeczeństwa ${ }^{68}$. Po tej decyzji

${ }^{64}$ Podobnie definiuje różnicę między ideami politycznymi de Gaulle’a i Action Française Aleksander Hall: „Od szkoły Maurrasa dzielił go już sam typ nacjonalizmu, który obejmował w jego wypadku także tradycję republikańską i budował zbiorową pamięć na wszystkich wydarzeniach francuskiej chwały, bez względu na ustrój i ideologię. Był to nacjonalizm bliższy wizji Barrèsa i Péguy niż Maurrasa" (idem, Idee polityczne i wizja Charles'a de Gaulle'a a doktryna Action Française, w: Nacjonalizm a konserwatyzm i monarchizm. Action Française i jej promieniowanie, op. cit.).

${ }^{65} \mathrm{R}$. Aubert, Kościół katolicki od kryzysu 1848 do pierwszej wojny światowej, w: Historia Kościoła, t. V, PAX 1985, s. 39-41. Interesującą analizę idei „Sillon” można znaleźć również w pracy Janusza Stefanowicza poświęconej temu ruchowi: idem, Chrześcijańska demokracja, PAX 1963, s. $146-160$.

${ }^{66}$ Pius X, Notre charge apostolic, Wydawnictwo Te Deum 2002.

${ }^{67}$ Ibidem.

${ }^{68}$ Warto przytoczyć fragment encykliki poddający ostrej krytyce ewolucję „Sillon”: „Był czas, kiedy Sillon jako taki, był wyraźnie katolicki. Nie uznawał innej poteggi duchowej niż katolicka i głosił pogląd, że demokracja będzie katolicka albo nie będzie jej wcale. Nadszedł jednak moment, kiedy zmienił zdanie. Pozostawił wówczas każdemu człowiekowi jego religię i filozofię, sam przestał uważać się za katolicki i sentencję: «demokracja będzie katolicka» zastapił inną: «demokracja nie będzie 
środowiska nawiązujące do tradycji Sillon nie miały już statusu ruchów religijnych, zachowały jednak jednoznacznie prorepublikańskie stanowisko. Wolno powiedzieć to o grupie Jeune République ${ }^{69}$, która związała się z obozem lewicy i chadeckiej Partii Demokratyczno-Ludowej współtworzącej w okresie międzywojennym blok republikańskiej prawicy. Działacze tej ostatniej, deklarujący się jako „republikanie serca i rozumu”,70, odegrali istotną rolę w Résistance jako współpracownicy de Gaulle’a. Trzeba wymienić przede wszystkim Georges'a Bidaulta, François Menthona, Marcela Prelota i Pierre-Henri Teintgena. Utworzony w 1944 roku Ruch Republikańsko-Ludowy (MRP) kontynuował tradycję chadeckiej PDL. Dysponując piękną kartą udziału w Résistance MRP był, obok Partii Komunistycznej i francuskich socjalistów zrzeszonych w SFIO, najsilniejszą partią IV Republiki.

Tymczasem de Gaulle nie był chrześcijańskim demokratą z właściwą tej szkole tendencją do nadawania chrześcijańskiej sankcji ustrojowi demokratycznemu. W żadnym razie nie podzielał radykalizmu społecznego Marca Sangniera. To powody, dla których opinia Mauriaca o silnych związkach de Gaulle'a z Sillon wskazuje na mylny trop inspiracji ideowych. Warto przywołać w tym kontekście mało znaną korespondencję de Gaulle'a z Maritainem z lat II wojny światowej. W liście z 1942 roku wybitny filozof sugerował de Gaullowi aby w wypowiedziach publicznych przywoływał wartości ewangeliczne jako źródło odrodzenia demokracji. Przywódca Wolnej Francji nie przyjął tej sugestii i odpowiedział, że republika ma dla niego sens ponadideologiczny i że powinna integrować Francuzów, a wyraźne odwołanie do wartości chrześcijańskich miałoby ten sam redukujący skutek co przywołanie liberalizmu demokratycznego jako idei podstawowej Wolnej Francji ${ }^{71}$.

Trzeba zauważyć, że de Gaulle nie kwestionował laickiego charakteru republiki, choć z pewnością odnosił się krytycznie do agresywnej wersji laicy-

antykatolicka», zresztą tak samo, jak nie będzie antyżydowska i antybuddyjska. Były to czasy tzw. większego Sillonu. Wezwano wówczas wszystkich robotników, reprezentujących każdą religię i każdą sektę, do budowy społeczeństwa przyszłości. Wymagano od nich jedynie, aby wyznawali ten sam ideał społeczny, szanowali każdą wiarę oraz by wnieśli pewien wkład energii duchowych" (ibidem).

${ }^{69}$ De Gaulle współpracował z pułkownikiem Emilem Mayerem, bliskim ruchowi Jeune République. Współdziałanie to związane było z prowadzoną przez De Gaulle'a kampanią na rzecz modernizacji armii, nie można go więc traktować jako wyrazu sympatii dla poglądów lewicowego nurtu chrześcijańskiej demokracji.

${ }^{70}$ „Jesteśmy republikanami z serca i rozumu... Nie przyjmujemy poglądu, że kwestia ustroju powinna być poddana dyskusji. Jesteśmy demokratami” (M. Prélot, Manuel politique, le programme du Parti Démocrate Populaire, Éditions Spes 1928, cyt. za: J. Stefanowicz, Chrześcijańska demokracja, op. cit., s. 156.

${ }^{71}$ Omówienie korespondecji de Gaulle'a z Maritainem znajdziemy w tekście Odile Rudelle, De Gaulle et La République, w: S. Berstein, O. Rudelle, Le modèle républicain, P.U.F. 1992, s. 395-396. De Gaulle wypowiedział w liście do Maritaina bardzo surową ocenę postaw większości biskupów wspierających Vichy i nie krył, że fakt ten utrudniał dodatkowo wyraźne odwołanie Wolnej Francji do wartości chrześcijańskich. 
$\mathrm{zmu}^{72}$. Po wojnie skoncentrował się na rozszerzeniu ustawodawstwa prorodzinnego. Kwestię publicznego wsparcia dla szkolnictwa wyznaniowego rozwiązał pomyślnie dla opinii katolickiej w 1959 roku. Był człowiekiem pobożnym, wedle świadectwa jego bratanka, François de Gaulle'a, duchownego ze zgromadzenia białych ojców, regularnie przystępował do komunii w każdą niedzielę. Nie czynił tego jednak na mszach związanych z uroczystościami państwowymi. Tak też się stało podczas mszy odprawionej w katedrze w Reims po podpisaniu z Konradem Adenauerem traktatu francusko-niemieckiego w dniu 7 lipca 1962 roku $^{73}$.

${ }^{72}$ „Czterej młodzi de Gaulle’owie otwarcie popierają Republikę. Ich przekonania są owocem idei, która przed laty kształtowała świadomość narodu. Kiedy zaczynają dyskutować, nic nie może ich powstrzymać (...) Aprobują nawet odseparowanie Kościoła od Państwa, mimo że wszyscy są żarliwymi katolikami. Równie żarliwie chcą służyć Republice" (G. Moll, Y. de Gaulle. Historia i życie, op. cit., s. 31-32).

${ }^{73}$ Warto przytoczyć wspomnienia ojca François de Gaulle'a, który często odprawiał mszę świętą w prywatnej kaplicy urządzonej przez prezydenta w Pałacu Elizejskim: „W piątek, mówi, dzwonił adiutant do Domu Ojców Białych, mieszczącego się przy ulicy Roger-Verlomme, gdzie w owych czasach byłem prowincjałem, aby zapytać, czy mógłbym przyjść w niedzielę, aby odprawić mszę cichą. Zwyczaj był taki, że dzwoniono do nas i jeśli byłem nieobecny, to jakiś inny członek naszego zgromadzenia zastępował mnie. Wzywano mnie tam średnio dwa lub trzy razy w miesiącu. Przychodziłem zawsze wcześniej, przygotowywałem szaty liturgiczne i czekałem na przyjście Generała. O 11.30 pojawiał się on w towarzystwie pani Generałowej, ubrany po cywilnemu lub w mundur, w zależności od obowiązków następujących danego dnia. Zawsze przy jego boku był obecny adiutant i czasem pozostali członkowie rodziny. Ceremonia trwała 45 min. Czasem wygłaszałem krótkie kazanie. Mój wuj i moja ciotka, oboje byli ludźmi głębokiej wiary, co niedzielę przyjmowali komunię świętą. Następnie zapraszali mnie na obiad. Był to skromny posiłek, do którego dołączali się ewentualni goście, którzy uczestniczyli we mszy. Atmosfera była przyjazna. Rozmowa, bardzo swobodna, krążyła wokół różnych wiadomości i aktualnych wydarzeń. De Gaulle, który wybrał na symbol Wolnej Francji krzyż lotaryński, mówił chętnie o swojej religii. Jego szeroko pojęta kultura doprowadziła do znajomości i respektowania innych religii, nawet jeśli jego własna prowadziła przez pobożność i korzenie chrześcijańskie. Jak można zapomnieć, że pomimo pobliskiej strzelaniny, pragnął, aby śpiewano Magnificat w katedrze Notre-Dame 26 sierpnia 1944 roku, w dniu wyzwolenia Paryża, i że 7 lipca 1962 roku w Reims, po podpisaniu z Konradem Adenauerem traktatu francusko-niemieckiego pojednania, zaprosił kanclerza na mszę w katedrze, aby modlić się o pokój? Otóż, mimo że ten czyn wniósł «dotyk sacrum» do tego wydarzenia i że Generał złożył swoje życie prywatne Bogu, z czego z resztą nie robił tajemnicy, tym razem nie przystąpił do komunii. Uważał, że jako głowa państwa nie powinien pozwolić sobie na publiczne praktyki religijne... Po spacerze w parku samochód żandarmów, który rankiem po mnie przyjechał, odwiózł mnie do ojców z III dzielnicy. Przed odjazdem mój wuj powtarzał często z czułością: «Nie jesteś kapłanem Pałacu Elizejskiego, to jest msza prywatna, którą odprawiasz, ponieważ nie jestem prezydentem katolików, ale wszystkich Francuzów. Nie należy mylić prezydenta Republiki z arcybiskupem Paryża». Oczywiście, również koncelebrowałem mszę podczas pogrzebu mojego czcigodnego wuja 12 listopada 1970 roku. Moje najbardziej poruszające wspomnienie sięga dnia moich święceń, kiedy to ukląkł na kolana, aby poprosić mnie o błogosławieństwo" (przeł. M. Miałkowska). Wspomnienia François de Gaulle’a opublikowała Caroline Pigozii, Laickość wedtug de Gaulle, „Paris Match”, 17.04.2011. Dodajmy, że podczas wizyty w Związku Radzieckim w czerwcu 1966 roku, przy okazji mszy w kaplicy francuskiej w Leningradzie, jako głowa państwa przyjął komunię, stosując tego dnia za granicą zasadę wolności wyznania, żeby wykonać oficjalny gest w pozbawionym wolności ZSRR. Wśród pozycji poświęconych stosunkowi de Gaulle'a do wiary i jej znaczenia w pracy publicznej trzeba wymienić: 
De Gaulle zawdzięczał nauczaniu społecznemu Kościoła świadomość społecznej odpowiedzialności państwa, konieczności przezwyciężenia konfliktów klasowych i poszukiwania równowagi społecznej. Tu ma źródło ideowe podjęta w latach 1944-1945 polityka uspołecznienia kapitalizmu, a także koncepcja stowarzyszenia kapitału i pracy z okresu Zgromadzenia Ludu Francuskiego oraz mająca konsekwencje ustrojowe idea partycypacji. Wydaje się, że był bliższy zachowawczemu nurtowi myśli chrześcijańsko-społecznej związanemu z nazwiskami Alberta de Mun i René de Tour du Pina. Nurt ten eksponował potrzebę solidarności i przezwyciężania egoizmu klasowego, nie wysuwał radykalnych postulatów społecznych i odrzucał egalitaryzm. To w jego łonie uformowal się korporacjonizm francuski. Katolicyzm społeczny w tej wersji był krytycznie nastawiony do dziedzictwa Rewolucji Francuskiej i miał sympatie monarchistyczne ${ }^{74}$. Albert de Mun pozytywnie odpowiedział na wezwanie Leona XIII i przyłączył się do republiki, uznawszy, że w jej ramach będzie możliwe urzeczywistnienie idei korporacyjnych i solidarystycznych. Wydaje się, że w myśli konstytucyjnej de Gaulle'a jedyną ideą pochodzącą spoza tradycji republikańskiej był korporacjonizm ${ }^{75}$. Po raz pierwszy wyraził ją w przemówieniu w Bayeux, lansując obecność w Senacie reprezentacji interesów gospodarczych i zawodowych. Idee korporacyjne próbował urzeczywistnić bez powodzenia w 1958 i 1969 roku, a na drodze stanęła mu kluczowa dla porządku republikańskiego zasada, w myśl której suwerenność przysługuje narodowi jako całości, co kwestionuje legitymację ciał pośredniczących do odrębnej reprezentacji. Z tego względu w trakcie prac nad konstytucją V Republiki przeciwko ustanowieniu ,segmentu” korporacyjnego w Senacie oponował gorąco Michel Debré ${ }^{76}$.

Fondation Charles de Gaulle, Charles de Gaulle chrétien, homme de État, sierpień 2011; C.G. Bardy, Charles le catolique, Plon, listopad 2011; A. Latreille, De Gaulle, La Libération et l'Eglise Catholique, Cerf, marzec 1978; M. Brisacier, La Foi du Général, Nouvelle Cité 1998; J.-M. Mayeur, Catholicisme social et Démocratie chrétienne. Principes romains et expériences françaises, Le Cerf 1986; Ph. Portier, Le général de Gaulle et le catholicisme. Pour une autre interprétation de la pensée gaulienne, «Revue historique» nr 602, kwiecień-czerwiec 1997, s. 533-562. Warto odnotować także materiały z konferencji poświęconej tej problematyce: Charles de Gaulle, chrétien, homme d'état - 13 et 14 novembre 2009, Paris, Fondation Charles de Gaulle.

${ }^{74}$ C. Brice, Essai d'une politique chrétienne en Europe jusqu'en 1914, w: P. Obry (red.) Nouvelle histoire des idées politiques, Hachette 1987. Czesław Strzeszewski przypominał stanowisko René Tour du Pina, prekursora idei korporacjonistyczych, poddającego krytyce Deklarację praw człowieka i obywatela. W jego opinii Deklaracja inspirowała liberalizm i socjalizm i odmawiała praw wszelkim zrzeszeniom istniejącym pomiędzy jednostką a narodem (C. Strzeszewski, Katolicka nauka społeczna, Odiss 1985, s. 240-241).

${ }^{75}$ Bardzo ciekawe uwagi o poglądach de Gaulle'a, które nie znalazły urzeczywistnienia w konstytucji V Republiki, zawarł Ricci w artykule poświęconym jej źródłom ideowym (J.C. Ricci, Les idées politiques à l'origine de la Constitution de 1958, w: Les 50 ans de la Constitution, Litec 2008.

${ }^{76}$ Documents pour servir à l'histoire de l'élaboration de la Constitution du 4 octobre 1958, Volume I: Des origines de la loi constitutionnelle du 3 juin 1958 à l'avant projet du 29 juillet 1958, La Documentation française 1987, s. 247. 
Aleksander Hall w biografii de Gaulle'a pisze, że w latach trzydziestych generał ,akceptował republikę i demokratyczny porządek, chociaż podtrzymywał swój krytycyzm wobec systemu parlamentarnego w kształcie, w jakim funkcjonował on we Francji" 77 . Trzeba zatrzymać się dłużej nad tą kwestią. Co oznaczała akceptacja republiki? Wydaje się, że najbliższa prawdy jest w tej kwestii francuska historyk Odile Rudelle, która na podstawie lektury notatek de Gaulle'a z okresu młodości wskazuje, że akceptował on Republikę jako trwały w czasach współczesnych sposób egzystencji Francji ${ }^{78}$. Z pomocą przychodziła mu sławna formuła Péguy, eksponująca ciagłość historii Francji: „Republika jedna i niepodzielna to nasze królestwo Francji" 79 . Można sądzić, że akceptacja Republiki była aktem rozumu, nie serca. Tak interpretował republikanizm de Gaulle'a znakomity francuski historyk Ren Rémond:

„De Gaulle jest przekonany, że w naszych czasach nie ma już innej zasady legitymizacyjnej, jak tylko suwerenność ludu, ani innego źródła władzy, jak tylko demokratycznie wyrażona wola ludu. W ten sposób de Gaulle okazuje się demokratą bardziej - być może ze względów racjonalnych niż z usposobienia, ależ czy nie dzieje się tak często z najbardziej zagorzałymi obrońcami określonego systemu? To przecież w wyniku rozumowania, w którym element kalkulacji miał większy udział niż żarliwość uczucia, Charles Maurras nawrócił się na ideę monarchiczną" ${ }^{\circ 0}$.

Wolno zatem sądzić, że już w latach trzydziestych de Gaulle akceptował aksjologię republikańską, pozostawiając jako otwartą kwestię konkretnego kształtu instytucjonalnego Republiki. Zauważmy, że współpracował z politykami republikańskimi, przede wszystkim Paulem Reynaud, który w pełni podzielał jego projekt unowocześnienia armii. Dzięki znajomości z pułkownikiem Emilem Mayerem, bliskim ruchowi „Jeune République”, poznał środowisko o wyraźnie republikańskiej orientacji i promował tam swoje koncepcje powstrzymania ekspansji Niemiec. Nie wahał się także przedstawić swoich koncepcji premierowi Leonowi Blumowi, przywódcy francuskich socjalistów ${ }^{81}$.

W tamtym czasie nie znał jeszcze pozytywnej odpowiedzi na kryzys ustrojowy III Republiki. Musiał mieć jednak wyraźną świadomość jej słabości. Od-

${ }^{77}$ A. Hall, Naród i państwo w myśli politycznej Charles'a de Gaulle'a, op. cit., s. 91.

${ }^{78}$ O. Rudelle, De Gaulle et République, op. cit.

${ }^{79}$ Ch. Péguy, w: E. Roussel, De Gaulle, t. I, op. cit., s. 35.

${ }^{80}$ René Rémond, podobnie jak Odile Rudelle, wskazywał, że tradycja rodzinna nie przeszkadzała mu w uznaniu zasad demokracji. „De Gaulle, przyszły prezydent, w swej rodzimej tradycji nie znajdował żadnej przeszkody dla zaakceptowania demokracji: jego ojciec był antydreyfusista a Odile Rudelle pokazała, że na jej formację intelektualną miał wpływ liberalny, katolicki periodyk «Correspondant»" (idem, Francuska prawica dzisiaj, Iskry 2008, s. 226).

${ }^{81}$ Ch. de Gaulle, Pamiętniki wojenne, t. I, op. cit., s. 19-20. 
rzucenie planu modernizacji armii opracowanego przez de Gaulle’a było następstwem nacisków na premiera Paula Reynauda, typowych dla hegemonii partii politycznych i rządów zgromadzenia. W Pamiętnikach wojennych de Gaulle wspominał, że praca w Generalnym Sekretariacie Obrony Narodowej (1932-1937), stałym organie przy prezesie rady ministrów, unaoczniła mu nietrwałość rządów i słabość państwa w warunkach supremacji parlamentu i hegemonii partii politycznych ${ }^{82}$.

\section{Przeciw Vichy - obrona tradycji republikańskiej.}

1. Słabość ustrojowa III Republiki ujawniała się w sposób dramatyczny w 1940 roku. Francuzi nie byli zdolni do stawienia czoła ekspansji Niemiec. Republika sama pozwoliła na unicestwienie swoich zasad w aktach konstytucyjnych kładących podwaliny Państwa Francuskiego. Simone Weil pisała, że w czerwcu 1940 roku doszło do ,depresji i abdykacji całego narodu” $\$$.

W tekście Prawowitość rząu tymczasowego w ten oto sposób przedstawiała szczególną pozycję de Gaulle’a:

„I tak, prawowitość nie jest skarbem, który skradziono narodowi francuskiemu, nie dokonał tego ani nieprzyjaciel, ani jakiś spisek w kraju. Naród francuski jako całość, począwszy od elit, a skończywszy na masach pracujących, otworzył dłoń i upuścił klejnot na ziemię, nie patrząc nawet, dokąd skarb się potoczy... W takich warunkach na czym właściwie polega związek de Gaulle - prawowitość? Na tym, że gdy skarb ten leżał na ziemi wzgardzony, on podniósł go, położył i oznajmił publicznie, że staje się jego strażnikiem aż do dnia, w którym właściciel będzie się w stanie o niego upomnieć" $" 84$.

De Gaulle strzegł „skarbu prawowitości” w zgodzie z tradycją republikańską. Po latach w Pamiętnikach wojennych mógł napisać, że „wyciąnął Republikę z grobu", gdy zawiodły elity i instytucje ustrojowe ${ }^{85}$. W czasie II wojny światowej de Gaulle powiązał patriotyzm państwowy z tradycją republikańską i przesądził o tym, że zasady republikańskie stały się niekwestionowaną podstawą powojennej Francji. Opinii tej nie może podważać fakt, że środowisko osób tworzących Wolną Francję miało pod względem ideowym charakter pluralistyczny, a wśród współpracowników generała znaleźli się również ludzie z kręgu Action Française ${ }^{86}$. Rzeczywiście w 1940 roku de Gaulle ujawnił zdol-

${ }^{82}$ Ibidem, s. 3-4.

${ }^{83}$ S. Weil, Pisma londyńskie, Brama, Książnica Włóczęgów i Uczonych 1994, s. 48.

${ }^{84}$ Ibidem, s. 48-49.

${ }^{85}$ Ch. de Gaulle, Pamiętniki wojenne, op. cit., t. III, s. 93.

${ }^{86} \mathrm{~W}$ opinii S. Giocantego, autora najnowszej biografii Maurrasa, sympatykami Action Française byli przyszli marszałkowie Leclerc i De Lattre de Tasigni, przyszły premier Pierre Messmer, Guillain de Benouville czy Jacques Renouvain (S. Giocanti, Maurras, Le chaos et lord re, Paris 2006, s. 431). 
ność do gromadzenia wokół siebie ludzi o wybitnych talentach i wyraźnie odmiennych poglądach. Wśród pierwszych Wolnych Francuzów byli chrześcijański demokrata Maurice Schuman, Gilbert Renaut (Remy), wychowany w szkole Action Française, i René Cassin - profesor prawa o jednoznacznie republikańskich i laickich poglądach ${ }^{87}$.

Stanowisko prawno-państwowe Wolnej Francji było jednoznaczne od czasu wydania 27 października 1940 roku w Brazzaville Manifestu o wysiłku Francuzów w czasie wojny ${ }^{88}$. W tym dniu de Gaulle wydał również ordonans organizujący władze publiczne w czasie wojny i ustanawiający Radę Obrony Imperium Francuskiego oraz deklarację organiczną wyjaśniającą motywy prawne i polityczne obu aktów ${ }^{89}$. Wszystkie te akty zostały wydane przez przywódcę Wolnych Francuzów w imieniu ludu i Imperium Francuskiego, co było wyrazem republikańsko-państwowego podejścia. De Gaulle wskazywał na lud jako podmiot suwerenności, deklarując działanie w imieniu republiki, państwa i imperium. Ordonans wydany w Brazzaville podkreślał ciąłość prawną z III Republiką i stanowił, że do czasu ,ustanowienia francuskiego rządu oraz legalnego i niezależnego od wroga przedstawicielstwa ludu francuskiego we wszystkich częściach wyzwolonego spod władzy wroga Imperium władze publiczne będą działały na podstawie francuskiego prawa sprzed 23 czerwca 1940 roku"90.

Manifest uznawał ,organ mający swą siedzibę w Vichy za niekonstytucyjny i podlegający najeźdźcy"91. W dokumencie czytamy:

„W chwili obecnej nie ma już prawdziwego rządu francuskiego. Mający swą siedzibę w Vichy organ, który pretenduje do tej nazwy, jest niekonstytucyjny i podlega najeźdźcy. W swym stanie zależności organ ten może być $i$ istotnie jest jedynie narzędziem używanym przez wrogów Francji przeciwko honorowi i interesom naszego kraju" $"$.

De Gaulle deklarował, że „władzę swą będzie sprawować w imieniu Francji i jedynie w jej obronie" i zobowiązywał się do zdania sprawy ze swych

${ }^{87}$ Uwagi o pluralizmie postaw ideowych w środowisku Wolnych Francuzów znajdziemy w pracy Aleksandra Halla poświęconej myśli politycznej de Gaulle’a, Naród i państwo w myśli politycznej Charles'a de Gaulle'a, op. cit., s. 124-127.

${ }^{88}$ Manifeste relatif à la direction de l'effort français dans la guerre, w: M. Duverger, Constitution et documents politiques, PUF 1996, s. 191.

${ }^{89}$ Ordonnance no 1 organisant les pouvoirs public pendunt la guerre et instituant le Conseil de défense de l'Empire (21 octobre 1940). Déclaration organique complétant le manifeste du 27 octobre 1940, w: M. Duverger, Constitution et documents politiques, op. cit., s. 192-196.

${ }^{90}$ Ibidem..

${ }^{91}$ Manifeste relatif à la direction de l'effort français dans la guerre, w: M. Duverger, Constitution et documents politiques, op. cit., s. 191.

${ }^{92}$ Ibidem. 
wysiłków przedstawicielom narodu francuskiego, skoro tylko będzie mógł ich swobodnie wybrać"93. Ten ostatni motyw będzie się powtarzał w kolejnych dokumentach Wolnej Francji, Francji Walczącej, Francuskiego Komitetu Narodowego i Francuskiego Komitetu Wyzwolenia Narodowego, stanowiąc gwarancję powrotu do republikańskich i demokratycznych form ustrojowych.

Deklaracja organiczna, uzupełniająca Manifest, jeszcze mocniej występowała w obronie zasad Republiki i w ten sposób legitymizowała działanie Wolnej Francji. De Gaulle stwierdzał, że Vichy „bezskutecznie stara się uzasadnić swoje powstanie i istnienie pod pozorem zmiany ustaw konstytucyjnych, co jest jedynie rażącym i powtarzającym się pogwałceniem Konstytucji francuskiej"94. Według ogłoszonej deklaracji ze względu na to, że całe terytorium Francji znajdowało się pod bezpośrednią lub pośrednią kontrolą wroga, „organ nazywany rządem Vichy, utrzymujący, że zastępuje Rząd Republiki, nie korzystał ze swobody będącej warunkiem pełnienia władzy" ".5 . Dokument wymieniał w sposób szczegółowy naruszenia norm konstytucyjnych w trakcie kształtowania się władzy Vichy, wskazując na złamanie procedury rewizji konstytucji oraz na to, że Prezydent Republiki bez złożenia dymisji został pozbawiony praw i prerogatyw związanych z jego urzędem. Deklaracja przypominała, że ,zgodnie z postanowieniami Konstytucji z 1875 roku, projekt rewizji musi być poddany pod głosowanie w obu izbach parlamentu - Izbie Deputowanych i Senacie obradujaccych oddzielnie. Dopiero po wyczerpaniu tej procedury projekt rewizji konstytucji jest przedkładany Zgromadzeniu Narodowemu, które może się zebrać jedynie w Wersalu". De Gaulle prezentował stanowisko, że doszło tym samym do naruszenia zasad ,uznawanych przez głównych prawodawców Republiki Gambettę i Ferry'ego, za niezbędną gwarancję pozwalającą uniknąć pośpiesznego i podstępnego przeprowadzenia zmiany Konstytucji" ${ }^{\prime 96}$. Deklaracja zarzucała Vichy, że zmiana konstytucji miała miejsce poza Wersalem, choć ustrojodawca

„nie przewidywał, że kiedykolwiek będzie można wykorzystać nieszczę́liwą sytuację Parlamentu, wygnanego i rozproszonego przez nacierające wojska, by zwołać go w głównym mieście departamentu i przez zastraszenie zmusić do podniesienia ręki na podstawowe prawa Republiki" ${ }^{\prime 97}$.

Ponadto dokument podkreślał, że właściwa procedura zmiany konstytucji wymagała przedstawienia projektu jej rewizji oraz rozpatrzenia go przez Zgromadzenie Narodowe ,artykuł po artykule”. Tymczasem doszło do

\footnotetext{
${ }^{93}$ Ibidem.

${ }^{94}$ Ibidem, s. 193.

${ }^{95}$ Ibidem.

${ }^{96}$ Ibidem, s. 194.

${ }^{97}$ Ibidem.
} 
„podjęcia decyzji równie niekonstytucyjnej, jak bezsensownej, o powierzeniu osobie trzeciej prawdziwego pełnomocnictwa in blanco, co było równoznaczne z opracowaniem przez nią i wprowadzeniem w życie nowej konstytucji" ${ }^{98}$.

Trzeba przypomnieć, że ustawa konstytucyjna z 10 lipca 1940 roku dawała rządowi pod przewodnicwtem marszałka Pétaina władzę wydania i promulgowania Konstytucji Państwa Francuskiego w formie jednego lub kilku aktów. De Gaulle uznawał, że zapowiedź ta nie ma wartości i znaczenia, ,skoro rzekomy przywódca Państwa może wedle swojego życzenia ustalać skład przyszłych zgromadzeń, a także warunki ratyfikacji" ${ }^{99}$.

Deklaracja przypominała również, że w przypadku gdy parlament nie mógł swobodnie podejmować decyzji, Francja mogła ujawnić swą wolę za pośrednictwem rad generalnych, które zgodnie z ustawą z 15 lutego 1872 roku mogły w sytuacjach nadzwyczajnych zając się administrowaniem państwem. Jednak na mocy decyzji organu $z$ Vichy radom generalnym zostało odebrane prawo do zbierania się i podejmowania zadań publicznych. W wydanym w Brazaville dokumencie czytamy:

„Z braku wolnego i regularnie działającego parlamentu Francja mogła ujawnić swą wolę za pośrednictwem głosu rad generalnych; że zgodnie z ustawą z dnia 15 lutego 1872 roku oraz zważywszy na brak legalności organu z Vichy, rady generalne mogły się zająć administrowaniem państwem, ale że na mocy tak zwanego dekretu z 20 sierpnia 1940 roku wspomniany organ zabronił im zbierania się i na mocy tak zwanej ustawy z 12 października $1940 \mathrm{r}$. zastąpił je komisjami wybranymi przez władzę centralną"100.

\section{Deklaracja organiczna ponadto zwracała uwagę, że doszło do}

„stłamszenia prawa do swobodnego decydowania przez lud o ratyfikacji traktatów, uważanego we Francji za tradycyjne i święte, dające Szefowi Państwa, przez złożenie na nich własnego podpisu, możliwość zawierania i ratyfikowania wszystkich traktatów, nawet traktatów pokojowych lub dotyczących zrzeczenia się terytoriów, które naruszają integralność, niepodległość a nawet istnienie Francji, jej kolonii oraz państw będących pod jej protektoratem lub będących jej terytorium mandatowym"101.

De Gaulle nie tylko wskazywał na naruszenie poszczególnych norm konstytucji, ale podniósł zasadniczy dla republikańskiej tradycji konstytucyjnej argument. Deklaracja stwierdzała, że Vichy zniosło republikańską konstytucję wraz ze złamaniem zasady, w myśl której republikańska forma rządu nie może

\footnotetext{
${ }^{98}$ Ibidem.

${ }^{99}$ Ibidem.

${ }^{100}$ Ibidem.

${ }^{101}$ Ibidem.
} 
być przedmiotem jej rewizji. Doktryna prawno-państwowa Wolnej Francji stała na straży zasad Republiki i wyraźnie oponowała przeciw przywróceniu motywów właściwych tradycji monarchistycznej. Wspomniana Deklaracja przywoływała ustawę konstytucyjną z 1884 roku, gwarantującą nienaruszalność republikańskiej formy ustrojowej, i stwierdzała jej pogwałcenie przez ustawę konstytucyjną z 10 lipca 1940 roku. Co więcej, de Gaulle zarzucał Pétainowi, że decyzje Vichy wykluczały

„ze swych tak zwanych aktów konstytucyjnych słowo Republika i przyznawały szefowi tak zwanego Państwa Francuskiego władzę tak dużą, jak w przypadku monarchy absolutnego, którą może, jeśli zechce, sprawować przez całe życie lub przekazać ją każdej wybranej przez siebie osobie, a nawet uczynić tę władzę dziedziczną"102.

2. De Gaulle nie zmienił stanowiska w sprawie prawowitości i legalności władz państwowych w trudnym dla niego momencie kształtowania się jedności władz działających w imieniu Francji po zajęciu Afryki Północnej przez wojska aliantów. Przypomnijmy, że po inwazji aliantów w Afryce Północnej jesienią 1942 roku zastępca marszałka Pétaina i głównodowodzący wojsk francuskich generał Darlan po walce z Amerykanami zdecydował się na porozumienie z nimi i został przez nich uznany za partnera politycznego. 11 listopada 1942 roku, a więc w momencie zajęcia przez Niemcy strefy wolnej od okupacji, generał Darlan przejął władztwo na tym terytorium jako Wysoki Komisarz Francji rezydujący w Afryce francuskiej. Władze tworzone przez niego opierały się w ogromnym stopniu na dostojnikach i urzędnikach Państwa Francuskiego. Ordonans Wysokiego Komisarza z 7 grudnia został wydany zgodnie z legalizmem w ujęciu Vichy, na podstawie aktu konstytucyjnego z dnia 10 lutego 1941 roku i miał „obowiązywać jako prawo Państwa Francuskiego”103. Wydany przez Darlana ordonans powołał Radę Imperialną jako ciało opiniodawcze współpracujące z Wysokim Komisarzem i zwoływane przez niego. Artykuł 2 ordonansu stanowił, że „Rada Imperialna zbiera się okresowo na wezwanie Wysokiego Komisarza Francji rezydującego w Afryce francuskiej, w celu zbadania istotnych kwestii interesujących Imperium”. Niespełna dwa tygodnie później, 23 grudnia 1942 roku, Wysoki Komisarz Francji rezydujący w Afryce francuskiej utworzył konsultacyjny komitet ustawodawczy.

Po zabójstwie generała Darlana głównodowodzącym wojsk cywilnych i wojskowych w Afryce został generał Henri Giraud ${ }^{104}$. Spór w procesie jedno-

${ }^{102}$ Ibidem.

${ }^{103}$ Ordonnance no du 7 portant reation d un Conseil imperial, w: M. Duverger, Constitution et documents politiques, dz. cyt., s. 199.

${ }^{104}$ Henri Giraud (1879-1949), generał, dowódca VIII Armii. Po upadku Francji został uwięziony przez Niemców, w 1942 roku zbiegł z niewoli i przedostał się do Algierii. Po inwazji Ameryka- 
czenia się dwóch ośrodków władzy skupionych wokół generałów Girauda i de Gaulle'a miał wymiar polityczny i legitymizacyjny. W lutym 1943 roku de Gaulle przedstawił na konferencji prasowej w Londynie swoje stanowisko wobec francuskiego ośrodka władzy w Afryce Północnej i stwierdził, że oczekuje od generała Henri Girauda jednoznacznego zerwania z prawodawstwem Vichy i opowiedzenia się za porządkiem republikańskim i demokratycznym $^{105}$. De Gaulle przeciwstawiał prawowitość Republiki prawowitości Vichy i domagał się jednoznacznego wyboru tradycji republikańskiej. Uważał, że władza w Afryce Północnej, ,uchylając się od określenia swojej podstawy, stanowi źródło zamieszania i konfuzji” ${ }^{106}$. Dodawał, że „dla olbrzymiej większości Francuzów wyzwolenie oznacza jednocześnie ponowne ustanowienie Republiki" ${ }^{107}$. W odpowiedzi na pytania dziennikarzy argumentował, że nie może przesądzać, w jaki sposób dojdzie do przywrócenia Republiki, ale że Francja Walcząca jest przekonana, że system republikański jest jedyną podstawą prawowitości i trudno sobie wyobrazić wyrażenie woli i godności ludu francuskiego inaczej niż na podstawie ustaw Republiki ${ }^{108}$. Domagał się nie tylko akceptacji, ale także aplikacji ustaw republikańskich, a w szczególności przywrócenia swobód: wolności prasy, wolności osobistej, wolności zgromadzeń, wolności opinii obowiązujących w tej części Imperium Francuskiego, która znajdowała się w gestii Francji Walczącej. Uważał, że w Algierii powinny być przywrócone kompetencje departamentalnych rad generalnych, które według ustaw mają prawo zajmować się administracją ogólną, i opowiadał się za powołaniem Narodowej Rady Konsultacyjnej, która w braku możliwości działania parlamentu będzie pełnić rolę substytuującą przedstawicielstwa narodowego $^{109}$.

Presja de Gaulle'a okazała się skuteczna. Deklaracja i ordonans z 14 marca 1943 roku wydany przez generała Henri Girauda, jako komendanta sprawującego szefostwo cywilne i wojskowe, w sprawie ważności ustawodawstwa obowiązującego na podległym mu terytorium, był już krokiem w stronę linii interpretacyjnej głoszonej przez Wolną Francję. Akt rewidował stosunek do prawodawstwa Vichy, uznając je za wychodzące ze źródła, które nie może być

nów w Afryce Północnej i zabójstwie Darlana był głównym partnerem Amerykanów, sprawował wtedy funkcję komisarza cywilnego i wojskowego. Od czerwca 1943 roku wraz z de Gaulle'em kierował Francuskim Komitetem Wyzwolenia Narodowego (FKWN) jako jego współprezydent. W kwietniu 1944 roku odsunięty przez de Gaulle'a, stracił wpływ na działania FKWN. Zob. G. de Charbonnieres, Le Duel Giraud - de Gaulle, Plon 1984.

${ }^{105}$ Ch. de Gaulle, Discours et messages 1940-1946, Plon 1970, s. 260-269.

${ }^{106}$ Ibidem, s. 261-262.

${ }^{107}$ Ibidem.

108 „Mais nous sommes..... convaincus que régime republicainnest seul legitime et je ne vois pas commnet on serait d' accord avec volonté et la dignité du peuple français, sinon sur la base des lois de la République" (Ch. de Gaulle, Discours et messages 1940-1946, op. cit., s. 262).

${ }^{109}$ Ibidem, s. 265. 
uznane, jako że nie było efektem „swobodnego wykonywania suwerenności” i ,podlegało uprzedniej zgodzie wroga" ${ }^{110}$.W dokumencie mówi się, że ustawodawstwo uchwalone po 22 czerwca 1940 roku jest pozbawione fundamentów prawowitości i dlatego ordonans wyraźnie anulował wszystkie wydane po tej dacie akty konstytucyjne, ustawy i dekrety. W deklaracji generał Henri Giraud deklarował zachowanie szacunku dla terytoriów, praw i interesów Francji w kształcie sprzed 22 czerwca 1940 i przyjmował zobowiązanie do zdania sprawy z działalności przed rządem powołanym przez lud francuski po wyzwoleniu Francji. Henri Giraud anulował akty prawne Vichy bez potępiania reżimu i bez zapowiedzi aplikacji ustaw Republiki. Różnica ze stanowiskiem Wolnej Francji jest widoczna, de Gaulle bowiem frontalnie odrzucał prawowitość i legalność Vichy oraz wyraźnie i pozytywnie definiował swój związek z zasadami Republiki.

Pomimo tych różnic stanowisko Henri Girauda otwierało drogę do utworzenia nowych władz na bazie prawowitości i legalności w rozumieniu de Gaulle'a. Trzy miesiące później przywódca Wolnej Francji rozwiązał po swojej myśli zarówno polityczne, jak i legitymizacyjne kwestie unifikacji sił francuskich w Afryce Północnej i doprowadził do zawarcia porozumienia z generałem Henri Giraudem w myśl zasad głoszonych konsekwentnie od jesieni 1940 roku. 26 maja wydał ostatni ordonans jako przewodniczący Komitetu Narodowego na podstawie raportu opracowanego przez profesora René Cassina ${ }^{111}$. Ordonans w art. 2 stanowił:

„Nowa lub zmodyfikowana organizacja władz będzie miała za cel jedność francuską i zapewnienie wykonywania suwerenności narodowej i dodawał, że musi być zgodna z fundamentalnymi zasadami Republiki" ${ }^{112}$.

Wydany przez de Gaulle'a akt prawny podkreślał konieczność zachowania ciągłości władz publicznych i przyjęcia ,zasad, które pozwolą Narodowi wyrazić swoją wolę w jak najszybszym możliwym terminie"113.

W czerwcu 1943 roku został wydany dekret, który wprowadził bardziej precyzyjną i szczegółową regulację w sferze organizacji i funkcjonowania Francuskiego Komitetu Wyzwolenia Narodowego. Podpisany przez de Gaulle'a i Girauda dekret definiował Komitet jako organizm rządowy i stanowił, że podejmuje on decyzje większością głosów przy założeniu solidarnej

${ }^{110}$ Ordonnance de 23 décembre 1942, w: M. Duverger, Constitution et documents politiques, op. cit., s. 200.

${ }^{111}$ R. Cassin, Rapport au president du Comité National, w: M. Duverger, Constitution et documents politiques, op. cit., s. 200-201.

${ }^{112}$ Le Comité français de la Libération nationale et le Gouvernement provisoire de la république. Ordonnance no 55, w: M. Duverger, Constitution et documents politiques, op. cit., s. 202.

${ }^{113}$ Ibidem. 
i wspólnej odpowiedzialności członków komisarzy. Przyjęto również zasadę (art. 8), że ordonans jest konieczną formą prawną materii, która przed 16 czerwca podlegała regulacji ustawowej. Warto zauważyć, że od momentu ustanowienia Komitetu akty prawne były publikowane w Dzienniku oficjalnym Republiki Francuskiej, wcześniej w Dzienniku oficjalnym Francji Walczacej, co było symbolicznym wyrazem odtworzenia tymczasowych władz państwowych $^{114}$.

3. Bardzo istotnym krokiem na drodze do przywrócenia Republiki było spełnienie wyrażonej już w 1941 roku idei powołania Tymczasowego Zgromadzenia Konsultacyjnego. Ordonans w tej sprawie został wydany 17 września 1943 roku. Tymczasowe Zgromadzenie Konstytucyjne miało mieć zadanie „najszerszego wyrażania opinii narodowej”115. W skład Zgromadzenia weszli przedstawiciele ruchu oporu z metropolii i spoza metropolii, przedstawiciele rad generalnych i przedstawiciele tych członków Senatu i Izby Deputowanych, którzy sprzeciwili się kapitulacji i nie upoważnili marszałka Pétaina do wykonywania władzy konstytucyjnej. Członkami Zgromadzenia nie mogli zostać funkcjonariusze Państwa Francuskiego ani osoby wspomagające przedsiębiorstwa wroga czy zwalczające aktywność ruchu oporu.

Zgromadzenie było ciałem opiniodawczym i formułowało swoje zdanie w kwestiach przedstawionych przez Komitet. Jednakże w kwestii projektu budżetu i pożyczek przekraczających sumę $500 \mathrm{mln}$ franków zasięgnięcie opinii Zgromadzenia miało charakter obowiązkowy. Krytyczna opinia Zgromadzenia w sprawie redukcji wydatków i powiększenia obciążeń fiskalnych oznaczała konieczność ponownego rozpatrzenia sprawy. Ordonans stanowił, że Zgromadzenie będzie opiniować projekt ordonansu regulującego uformowanie rządu tymczasowego. Wydaje się, że waga Zgromadzenia była większa niż określone w ordonansie kompetencje, które w nadzwyczajnym okresie, jakim była wojna, nie mogły odpowiadać kompetencjom parlamentu mającego mandat demokratyczny. Należy podkreślić, że decyzja o utworzeniu ciała quasi-parlamentarnego umacniała prawowitość i legalność Wolnej Francji. Potwierdzała także wyrażaną od jesieni 1940 roku intencję przekazania władzy przedstawicielstwu narodowemu wyłonionemu po wyzwoleniu i zapowiadała reakcję w stosunku do funkcjonariuszy Vichy ${ }^{116}$.

${ }^{114}$ Ordonnance du 3 juin 1943 portant institution du Comitet Français de la libération nationale, w: M. Duverger, Constitutions et documents, op. cit., s. 202-203.

115 Ordonance du 17 septembre 1943 portant constitution d une Assemblee Consultative Provisoire, w: M. Duverger, Constitution et documents politiques, op. cit., s. 204-208.

${ }^{116}$ Bardzo interesujące i reprezentatywne dla Wolnej Francji było przemówienie René Capitanta wygłoszone na forum Tymczasowego Zgromadzenia Konsultacyjnego (idem, Que sera l' Assemblée Provisoire (Combat d'Alger 30.07.1943 r.), w: H. Michel, B. Mirkine-Guetzevitch, Les idées politiques et sociales de la Résistance, op. cit., s. 265-268. 
Serge Berstein, autor pracy poświęconej historii gaullizmu, uważa, że między majem a listopadem 1943 roku gaullizm polityczny przeszedł fundamentalną mutację.

„Logika sformułowanego w roku 1940 wyboru polityki przeciwnej Vichy (...) doprowadziła do połączenia arepublikańskiego z pochodzenia nacjonalizmu z podstawowymi zasadami demokracji liberalnej, do przejścia z proklamowanej apolityczności do woli przywrócenia wartości republikańskich. Przemiana zakończyła się w Algierze pomiędzy czerwcem a listopadem 1943 roku, powodując przejście państwa gaullistowskiego w stadium wirtualnego państwa republikańskiego, gotowego przystapić do przywrócenia w wolnej Francji republikańskiej praworządności”"117.

Wydaje się, że Berstein nie w pełni docenia fakt, że prorepublikański kształt doktryny prawnej Wolnej Francji został określony już w 1940 roku ${ }^{118}$.

W pierwszej połowie 1944 roku podjęte przez Francuski Komitet Wyzwolenia Narodowego przygotowania do wyzwolenia terytorium metropolii miały wyraz prawny i instytucjonalny. Wydany 21 kwietnia 1944 roku ordonans regulował organizację władz publicznych we Francji po wyzwoleniu i zapowiadał „zwołanie Zgromadzenia Narodowego jako Konstytuanty, skoro tylko okoliczności pozwolą na normalne wybory, w terminie nie późniejszym niż rok po całkowitym uwolnieniu terytorium kraju"119. Ordonans zapowiadał ustanowienie praw wyborczych dla kobiet, a także ustanawiał terytorialną organizację Komitetu i nowe zasady funkcjonowania Zgromadzenia. W myśl ordonansu kompetencje Zgromadzenia zwiększały się (art. 27-30). Zgromadzenie miało wybierać bezwzględną większością głosów prezydenta rządu tymczasowego, co oznaczało przyjęcie mechanizmu właściwego dla rządu parlamentarnego (art. 25). W dniu 3 czerwca Francuski Komitet Wyzwolenia Narodowego przekształcił się w Rząd Tymczasowy Republiki Francuskiej i odtąd funkcjonował na zasadach określonych w Algierii aż do 2 listopada 1945 roku, kiedy weszła w życie ustawa konstytucyjna uchwalona w drodze referendum.

Trudno o bardziej jednoznaczne opowiedzenie się za zasadami Republiki. Na ich podstawie Wolna Francja uznawała Vichy za reżim pozbawiony nie tylko przymiotu prawowitości, ale także legalności. Trzeba też podkreślić, że środowiska tworzące Résistance miały jednoznacznie republikański charakter. Je-

${ }^{117}$ S. Berstein, Histoire du gaullisme, Perrin 2001, s. 64.

${ }^{118}$ Mirkine-Guetzevitch nie zgadzał się z opinią o antyrepublikanizmie czy arepublikanizmie de Gaulle'a. Autor wskazywał wprawdzie brak republikańskiej pasji i emfazy w wypowiedziach de Gaulle'a, ale interpetował jego linię jako jednoznacznie prorepublikańską (H. Michel, B. Mirkine-Guetzevitch, Les idées politiques et sociales de la Résistance, op. cit., s. 116.

${ }^{119}$ Ordonnance du 21 avril 1944 portant organisation des pouvoirs publics en France aprês la libération, w: M. Duverger, Constitution et documents politiques, op. cit., s. 210-213. 
den z uczestników ankiety, w której wzięli udział reprezentatywni członkowie Ruchu Oporu deklarował:

„Idea republiki zrodziła się sama z siebie, oczyszczona i odnowiona, z poświęceń, bólu, koleżeństwa Résistance... Dlatego też tak jak za czasów pierwszej republiki słowa «patrioci» $\mathrm{i}$ »republikanie« znów stały się synonimami. Republika odrodziła się pod znakiem bezkompromisowego patriotyzmu" ${ }^{\prime 20}$.

Doktryna Wolnej Francji była dziełem René Cassina, który zasługuje na szczególną uwagę ze względu na rolę, jaką odegrał w europejskiej kulturze prawniczej XX wieku. Profesor Cassin (1887-1976) pochodził z rodziny o żydowskich korzeniach i miał, jak wspomniałem, jednoznacznie republikańskie i laickie przekonania. W 1940 roku René Cassin miał już silną pozycję zawodową jako znawca prawa publicznego. W Londynie brał czynny udział w pracach inspirujących powstanie UNESCO i pracach aliantów nad nową deklaracją promującą prawa jednostki i obywatela w skali międzynarodowej. Był głównym autorem historycznej Deklaracji praw człowieka i obywatela ONZ, za co otrzymał Nagrodę Nobla w 1968 roku. Po wyzwoleniu kierował Radą Stanu (do 1960 roku), umacniając jej autorytet, był również aktywnym uczestnikiem prac nad projektem konstytucji V Republiki ${ }^{121}$.

Przegrana i kompromitacja Vichy musiała gruntownie osłabić znaczenie tradycji ideowych krytycznych wobec Republiki. Wydaje się jednak, że nie można lekceważyć znaczenia poglądów i decyzji samego de Gaulle'a. Przywódca Wolnej Francji ugruntował tradycję republikańską dzięki konsekwentnej polityce opartej na zwartej i przemyślanej doktrynie. Wbrew opinii René Rémonda doktryna Wolnej Francji kwestionowała nie tylko prawowitość, ale także legalność Vichy ${ }^{122}$. Stanowisko de Gaulle'a w tej kwestii nigdy nie było powszechne akceptowane. Wspomnijmy wreszcie, że linia interpretacyjna de Gaulle’a budziła wątpliwości nawet w szeregach Wolnych Francuzów, o czym świadczą choćby wspomnienia Raymonda Arona, w których odnosił się on z dystansem do jednoznacznego potępienia Vichy i poglądów prawnych René Cassina $^{123}$.

${ }^{120}$ H. Michel, B. Mirkine-Guetzevitch, Les idées politiques et sociales de la Résistance, op. cit., s. 96.

${ }^{121}$ C. Andrieu, P. Braud, G. Piketty, Dictionnaire de Gaulle, Editions Robert Laffont 2006. Informacje o pracach René Cassina nad UNESCO i nową deklaracją praw człowieka i obywatela można znaleźć w wyborze dokumentów Résistance (H. Michel, B. Mirkine-Guetzévitch, Les idées politiques et sociales de la Résistance, op. cit., s. 12-14. Dorobek René Cassina jako wiceprzewodniczącego Conseil d'Etat został ostatnio wnikliwie opisany przez Catherine Teitgen-Colly, René Cassin, Vice President du Conseil d'Etat, «Revue du Drôit Public» nr 1/2011.

${ }^{122}$ R. Rémond, Francuska prawica dzisiaj, op. cit., s. 220.

${ }^{123}$ R. Aron, Widz i uczestnik, CDN 1984, s. 61-62. 


\section{Rekonstrukcja legalności republikańskiej.}

1. Rétablissement de la légalité républicaine, ogłoszone w sierpniu 1944 roku, było zatem logicznym następstwem doktryny prawno-państwowej Wolnej Francji ${ }^{124}$. To prawda, że de Gaulle nie chciał proklamować republiki w paryskim ratuszu zgodnie $\mathrm{z}$ tradycją rewolucyjna, jak sugerował to Georges Bidault 25 sierpnia 1944 roku. Odmówił tym samym przejęcia władzy na warunkach Résistance zdominowanego przez ruch komunistyczny. Wskazywał na to już André Siegfried w książce analizującej przejście od III do IV Republi$\mathrm{ki}^{125}$. Budowana konsekwentnie od Manifestu z Brazaville doktryna pozwalała mu na ogłoszenie ciagłości Republiki i stwierdzenie:

„Republika nigdy nie przestala istnieć. Wolna Francja, Francja Walcząca, Francuski Komitet Wyzwolenia Narodowego kolejno ją ucieleśniały. Vichy nie miało znaczenia prawnego w życiu narodu. Sam jestem prezydentem Rządu Republiki, dlaczego miałbym ją proklamować?" 26 .

W książce Demokracja francuska Konstanty Grzybowski świetnie ujął pozycję, w jakiej znajdował się przywódca Wolnych Francuzów, gdy stał na czele rządu tymczasowego w 1944 roku: ,de Gaulle był kontynuacją prawną III Republiki, był jednocześnie drogą ku odnowieniu demokracji"127. Polityka de Gaulle'a w latach 1944-1945 określiła fundamenty ustrojowe powojennej Francji. Zanim przedstawił on w Bayeux w czerwcu 1946 roku własną wizję reform konstytucyjnych, wprowadził zmiany, które okazały się podstawowymi zasadami IV i V Republiki.

2. Trzeba wskazać na cztery kwestie, które okazały się zasadnicze dla powojennego kształtu państwowości francuskiej. Po pierwsze, ,rekonstrukcja legalności republikańskiej” została dokonana z zachowaniem dyscypliny i ciagłości instytucji państwowych. Ordonans z 7 sierpnia 1944 roku „o przywróceniu legalności republikańskiej” pozwolił na połączenie delegalizacji Vichy z jednoczesnym zachowaniem ciagłości działań instytucji państwowych ${ }^{128}$. Ordonans z 9 sierpnia 1944 roku stwierdzał co do zasady nieważność wszelkich aktów i re-

${ }^{124}$ L'ordonnance du 9 août 1944 relative au rétablissement de la légalité républicaine sur le territoire continental, w: M. Duverger, Constitution et documents politiques, op. cit., s. 213.

${ }^{125}$ A. Siegfried, De la III a la IV République, op. cit., s. 126.

${ }^{126}$ Ch. de Gaulle, Pamiętniki wojenne, przeł. J. Nowacki, op. cit., t. 2, s. 330. W tym wypadku uważam, że Konstanty Grzybowski nie miał racji, pisząc, że de Gaulle przeciął spory formalistów dopiero w sierpniu 1944 roku, gdy proklamował nielegalność rządu Vichy. W rzeczywistości ordonans z 9 sierpnia 1944 roku o rekonstrukcji legalności republikańskiej zamykał proces zainicjowany jesienią 1940 roku (zob. K. Grzybowski, Demokracja francuska, op. cit., s. 161).

${ }^{127}$ K. Grzybowski, Demokracja francuska, op. cit., s. 161.

${ }^{128}$ L'ordonnance du 9 août 1944 relative au rétablissement de la légalité républicaine sur le territoire continental, w: M. Duverger, Constitution et documents politiques, op. cit., s. 213. 
gulacji prawnych promulgowanych po 16 czerwca 1940 roku. Jednocześnie wprowadzał wymóg wyraźnego określenia nieważności. Nieważność została wyraźnie stwierdzona w przypadku ustawy konstytucyjnej z 10 lipca 1940 roku, aktów mających rangę konstytucyjną, aktów ustanawiających nadzwyczajne jurysdykcje, aktów narzucających roboty przymusowe na rzecz wroga, odnoszących się do stowarzyszeń tajnych i wprowadzających jakąkolwiek dyskryminację w odniesieniu do Żydów. W pozostałych przypadkach zakładano stosowanie okresu przejściowego w procesie usuwania skutków prawnych aktów Vichy, a nawet dopuszczano możliwość uznania „niektórych sytuacji zastanych, których cofnięcie wprowadziłoby w państwie większe zamieszanie niż ich zatwierdzenie". Należy przypomnieć, że powojenna Francja zachowała niektóre akty prawne Vichy, przede wszystkim przepisy prorodzinne, emerytalne, antyalkoholowe ${ }^{129}$.

Po drugie, niezwykle istotnym składnikiem odbudowy państwa było unowocześnienie administracji i powołanie Państwowej Szkoły Administracji. École Nationale d'Administration, utworzona według projektu Michela Debré opracowanego jeszcze przed II wojną światowa, uformowała powojenne elity polityczne i biurokratyczne $\mathrm{z}$ pożytkiem dla jakości państwa ${ }^{130}$. ENA miała umożliwiać awans na wysokie stanowiska urzędnicze młodym ludziom spoza bogatego mieszczaństwa i tym samym demokratyzować elitę urzędniczą. Pisał o tym w Rachunku sumienia Francuza wybitny historyk francuski Marc Bloch $^{131}$. W tej samej logice umacniania państwa doszło do ścisłej współpracy de Gaulle'a z Radą Państwa (Conseil d'État), wyjątkową instytucją łączącą kompetencje najwyższej instancji sądownictwa administracyjnego i ciała konsultującego projekty ustaw. W dniu 31 lipca 1945 roku de Gaulle wydał ordonans, na mocy którego wszystkie projekty ustaw przedstawione przez rząd musiały być poddane procedurze konsultacji przez Radę Stanu ${ }^{132}$. De Gaulle zachował szczególny respekt dla Rady Stanu po rezygnacji ze sprawowania władzy. Dominique Chagnollaud w tekście poświęconym roli administracji wyższego szczebla w IV Republice przywołuje list de Gaulle'a do René Cassina z 1951 roku, w którym manifestował on szczególne poparcie dla Rady Stanu jako „solidnego bastionu” państwa ${ }^{133}$.

${ }^{129}$ Należy polecić publikację zbiorową poświęconą przywróceniu legalności republikańskiej będącą owocem konferencji zorganizowanej przez Fondation Charles de Gaulle: eadem, Le rétablissement de la légalité républicaine, Complexe 1996.

${ }^{130}$ M. Debré, Un projet d'École nationale d'Administration, «Dalloz hebdomadaire » 1938, nr 7. De Gaulle tak wyjaśniał sens powołania tej instytucji: „Gdy nakreślona w ten sposób struktura przybierze ostateczne kształty, Państwo będzie miało w swych rękach nowe dźwignie zapewniające mu dostateczny wpływ na aktywność Francji, by mogło uczynić kraj silniejszym i bardziej promieniującym na zewnątrz" (idem, Pamiętniki wojenne, t. II, op. cit., t. III Wydawnictwo MON 1968, s. 104.

${ }^{131}$ M. Bloch, Rachunek sumienia Francuza, op. cit., s. 246-247.

132 J. Sauvé, Le Conseil d'État et la Constitution, R.F.D.C. 2009, nr 77.

${ }^{133}$ D. Chagnollaud, La haute administration au pouvoir? Les «Grands commis» de la IVe République, „Pouvoirs” 1996, nr 76. 
Po trzecie, polityka de Gaulle'a po wyzwoleniu budowała etatystyczny model gospodarki i społeczny charakter Republiki Francuskiej, potwierdzony przez regulacje konstytucyjne IV i V Republiki. Przypomnijmy, że rząd tymczasowy podjął decyzję o nacjonalizacji sektora bankowego, ubezpieczeniowego, energetycznego i weglowego oraz transportu lotniczego. W styczniu 1946 roku znacjonalizowano Bank Francji i wielkie banki depozytowe ${ }^{134}$. Walter Laqueur zwraca uwagę, że de Gaulle poszerzył zakres interwencjonizmu państwowego, wyraźnie już obecnego w polityce Francji. W tym okresie wprowadzono mechanizmy planowania gospodarczego, które stosowano w IV i V Republice ${ }^{135}$. W latach 1944-1945 rozszerzono zakres ubezpieczeń i rozbudowano wsparcie dla rodziny. De Gaulle i jego współpracownicy w pełni zaakceptowali orientację społeczną IV Republiki. Przypomnijmy, że konstytucja z października 1946 roku definiowała Francję jako republikę „,niepodzielną, świecką, demokratyczną i społeczną" (art. 1 Konstytucji z 13 października 1946 roku), a preambuła do konstytucji wyrażała zdecydowanie ukierunkowanie społeczne. Preambuła do konstytucji z 1946 roku potwierdzała „prawa i wolności człowieka uświęcone przez deklarację z 1789 roku i podstawowe zasady uznane przez ustawy Republiki", ogłaszała zasady polityczne, gospodarcze i społeczne. Wśród nich znalazło się prawo do pracy, prawa związkowe, prawo do strajku, a także prawo pracowników do ustalania warunków pracy i wpływu na prowadzenie przedsiębiorstwa. Preambuła deklarowała również prawo do opieki zdrowotnej, zabezpieczenia społecznego, wypoczynku, równy dostęp do wykształcenia, wyszkolenia zawodowego i kultury, a także deklarowała politykę wsparcia dla rodziny („Naród zapewnia jednostce i rodzinie warunki konieczne dla ich rozwoju"). Dawała także oparcie procesowi nacjonalizacji, stwierdzając:

„Każde dobro, przedsiębiorstwo, których eksploatacja ma charakter narodowej służby publicznej lub monopolu faktycznego albo też nabiera takiego charakteru, winno stać się własnością zbiorowości”136.

Widoczna jest zatem ciągłość między IV a V Republiką. Konstytucja z 1958 roku potwierdziła zasady niepodzielności, laickości, demokratyzmu i społecznego charakteru republiki, które uzyskały po wojnie status konstytucyjny. Zgodnie z doktryną Wolnej Francji konstytucje IV i V Republiki potwierdzały nienaruszalność republikańskiej formy rządów ${ }^{137}$.

${ }^{134}$ J. Baszkiewicz, Historia Francji, Ossolineum 1978, s. 700.

${ }^{135}$ W. Laqueur, Historia Europy 1945-1992, Puls 1993, s. 233.

${ }^{136}$ J. Godechot, La Constitution du 27 Octobre 1946, w: Les constitutions de la France, op. cit., s. $389-390$.

${ }^{137}$ Prawne i moralne znaczenie zakazu przywrócenia monarchicznej formy rządu omawia Nathalie Droin w niezwykle ciekawym tekście o reformie konstytucyjnej z 1884 roku. Autorka przy- 
Co więcej, ciągłość tradycji republikańskiej została pogłębiona, albowiem preambuła do Konstytucji V Republiki deklarowała przywiązanie do praw człowieka i zasad suwerenności narodowej, tak jak zostały one określone w Deklaracji z 1789 roku i uzupełnione przez preambułę do Konstytucji z 1946 roku. Otwierało to także możliwość uznania waloru konstytucyjnego „podstawowych zasad uznanych przez ustawy Republiki”, które po historycznym orzeczeniu Rady Konstytucyjnej weszły w skład bloku konstytucyjnego, stanowiąc część materialnej podstawy kontroli konstytucyjności ustaw $^{138}$.

Po czwarte, trzeba zauważyć, że de Gaulle ugruntował „legalność republikańską", wprowadzając istotną korektę w postaci instytucji referendum konstytucyjnego. Fundamentalne znaczenie miał ordonans z 17 sierpnia 1945 roku wprowadzający konsultację ludu francuskiego w drodze referendum $^{139}$. De Gaulle zarządził referendum, w którym przed wyborem Zgromadzenia Narodowego przyznał narodowi udział w pouvoir constituant, należącą do tej chwili wyłącznie do parlamentu. To obywatele w drodze referendum położyli kres istnieniu III Republiki, zadecydowali o wyborze Konstytuanty, terminie prac konstytucyjnych i o obowiązywaniu na przyszłość zasady, że projekt uchwalony przez Konstytuantę będzie podlegał zatwierdzeniu w drodze referendum.

De Gaulle mógł napisać w Pamiętnikach nadziei, że decyzja wtedy podjęta miała moc „konstytucyjnego precedensu”, osłabiającego potężną pozycję partii politycznych:

wołuje między innymi teorię Carla Schmidta definiującego różnicę między konstytucją w ścisłym tego słowa znaczeniu a ustawą konstytucyjną. Rewizja ustaw konstytucyjnych nie może podważać fundamentów aksjologicznych konstytucji. Zdaniem Natalie Droin, niemiecki teoretyk prawa dostarczył tym samym argumentów przemawiających za jurydycznym walorem zakazu rekonstrukcji monarchii (eadem, Rétour sur la loi constitutionnelle, R.F.D.C., nr 80/ 2009.

${ }^{138}$ L. Garlicki, Rada konstytucyjna a ochrona praw jednostki we Francji, Wydawnictwo Sejmowe 1993, s. 61-63.

${ }^{139}$ Ordonnance $n^{\circ}$ 45-1836 du 17 aoüt 1945, instituant une consultation du peuple français par voie de référendum et fixant le terme des pouvoirs de l'Assemblée consultative provisoire, w: M. Duverger, Constitution et documents politiques, op. cit., s. 224-226. W myśl ordonansu naród miał podjąć istotne decyzje przed wyborem Zgromadzenia Narodowego. Po pierwsze, miał zadecydować o kresie bądź trwaniu III Republiki przez referendalną odpowiedź na pytanie z art. 2 ordonansu: „Czy pragniesz, aby Zgromadzenie Narodowe było Konstytuantą?” Pozytywna odpowiedź na to pytanie oznaczała, że III Republika przestaje istnieć na mocy decyzji obywateli, nie zaś Zgromadzenia Narodowego. Po drugie, naród miał w drodze referendum przesądzić o kształcie ustroju władz tymczasowych do czasu wejścia w życie nowej Konstytucji, tworząc pewną równowagę w układzie władz i określić siedmiomiesięczny termin zakończenia prac nad nową konstytucją. Pytanie ujęte w art. 4 ordonansu dotyczyło tego, czy Zgromadzenie ma całkowitą swobodę w podejmowaniu decyzji, czy też jest związane wolą narodu. Po trzecie, ordonans wprowadzał do francuskiego systemu konstytucyjnego referendum konstytucyjne zatwierdzające. Oznaczało to, że Konstytuanta podlega weryfikacji narodu, do którego należy ostateczna decyzja o aprobacie rozwiązań konstytucyjnych. Regulacja ta została przyjęta w konstytucji IV Republiki. 
„Wszelako z myślą o przyszłości, zanim jeszcze zostało wybrane Zgromadzenie Narodowe, ustanowiłem referendum, tak że naród sam zadecydował, iż odtąd konstytucja, aby być prawomocna, musi uzyskać jego bezpośrednią aprobatę. Tym samym stworzyłem demokratyczny instrument, za pomocą którego pewnego dnia będę sam mógł ustanowić dobrą konstytucję zamiast tej, która niebawem miała być uchwalona przez partie i w ich interesie".

Znakomity francuski historyk i politolog André Siegfried słusznie zauważył, że referendum oznaczało przyjęcie zasady, iż „to naród, a nie Zgromadzenie dysponuje suwerennością" ${ }^{140}$. Odebranie monopolu na pouvoir constituant (władzę tworzenia konstytucji ) Konstytuancie i przyznanie udziału w niej narodowi w referendum zatwierdzającym konstytucję stanowiło ważny krok w stronę demokratyzacji republiki.

Wbrew powszechnie głoszonej tezie V Republika nie mogła powstać jako monarchia republikańska. Republika we Francji była dziełem Rewolucji Francuskiej i ukształtowała swe wartości w zasadniczej konfrontacji z tradycją monarchistyczną. Specyficznie rozumiana idea suwerenności narodu uformowana pod wpływem myśli Rousseau, idee niepodzielności i laickości republiki tworzyły całkowicie nowy model państwowości. W tej sytuacji synteza antagonistycznych tradycji nie była możliwa. De Gaulle, choć wychował się w rodzinie o sympatiach monarchistycznych, wyznawał patriotyzm państwowy i akceptował republikę jako trwały sposób egzystencji Francji. Jego poglądy dojrzewały pod wpływem republikańskich nacjonalistów Charles'a Peguy i Maurice Barres'a, nie zaś idei monarchistycznych. To z ich inspiracji ukształtował się patriotyzm państwowy de Gaulle'a, akceptujący republikę, inkluzywny w stosunku do różnych tradycji ideowych i zorientowany na wzmocnienie państwa jako narzędzia potęgi Francji. Myślał zatem nie tyle o pogodzeniu tradycji monarchistycznej z republikańską, ile o republice integrującej różne rodziny ideowe. Przyjęciu tej opcji służył również sposób pojmowania zobowiązań chrześcijańskich w sferze publicznej. W duchu tradycji katolicko-liberalnego „Correspondant” uważał, że idee chrześcijańskie nie muszą być skazane na porażkę w świecie ukształtowanym przez dziedzictwo Rewolucji.

W czasie II wojny światowej de Gaulle jako przywódca Wolnej Francji z wielką konsekwencją ugruntował tradycję republikańską w sporze z Vichy. W cytowanych wspomnieniach mógł napisać, że w 1940 roku ,wyciagnął Republikę z grobu", porzuconą przez zdecydowaną większość elity politycznej. W latach 1944-1946 jako szef rządu tymczasowego doprowadził do tego, że

${ }^{140}$ A. Siegfried, De la III à la IVe République, Grasset 1956, s. 130. 
zasady republikańskie stały się fundamentem powojennej Francji. W tym czasie de Gaulle rozbudował etatystyczny model gospodarki, ukształtował społeczny charakter Republiki Francuskiej. Decyzje te legły u podstaw konstytucjonalizacji zasad republikańskich i wyraźnych odwołań do Deklaracji praw człowieka i obywatela z 1989 roku w obu powojennych konstytucjach. Dlatego też V Republika mogła powstać jedynie jako zmiana instytucjonalna w ramach republikańskiej aksjologii.

\title{
PRESERVATION OF THE REPUBLIC. CHARLES DE GAULLE AND THE REPUBLICAN TRADITION (1940-1946)
}

\author{
$\mathrm{S} u \mathrm{~m}$ m a r y
}

Contrary to the common belief, the Fifth Republic could not be established as a Republican monarchy. In France the idea of a republic was created by the French Revolution and its values were shaped in the fundamental confrontation with the monarchist tradition. The specifically understood idea of a nation's sovereignty the formation of which was influenced by Rousseau's though, as well as the ideas of the indivisibility and lay character of the republic, constituted a completely new model of statehood. In such a situation, the synthesis of antagonistic traditions was not possible. Although de Gaulle had been brought up in a family of pro-monarchist attitudes, he followed the state patriotism idea and was a supporter of the Republic as a durable basis for France's existence. His views matured under the influence of French Republican nationalists Charles a Peguy and Maurice Barres, who inspired young de Gaulle and shaped his state patriotism. Later in his life de Gaulle's idea was not so much to reconcile the monarchist and the republican tradition, but to create a republic that would integrate different families of ideas. This concept was also induced by manner of understanding the role of Christian obligations due to the public sphere. Following the spirit of the Catholic-liberal "Correspondent" de Gaulle believed that in the world shaped by the Revolution's heritage Christian ideas do not need to be deemed to be defeated.

During World War II, de Gaulle, then the leader of Free France, consistently strengthened the French Republican tradition in the Vichy dispute. In the years 1944-1946, as head of the temporary government, he made sure that Republican principles constituted the foundations of the post-war France. De Gaulle developed the state model of economy and the social character of the French republic. His decisions laid the Republican principles in the French Constitution and refer clearly to the Declaration of Human and Civil Rights of 1989 in both French post war constitutions. That is why the $5^{\text {th }}$ Republic could only be established as an institutional variation within the framework of the Republican axiology. 


\section{SALUT DE LA RÉPUBLIQUE. \\ CHARLES DE GAULLE FACE À LA TRADITION RÉPUBLICAINE} (1940-1946)

Malgré la thèse communément proclamée, la Ve République ne pouvait pas naître comme une monarchie républicaine. La République en France est issue de la Révolution française. Elle a créé ses valeurs principalement à travers une confrontation avec la tradition monarchique. L'idée de souveraineté de la nation, comprise de manière particulière, formée sous l'influence de la pensée de Rousseau, les idées d'indivisibilité et de laïcité de la république créent un modèle tout à fait nouveau de l'État. Dans cette situation, procéder à une synthèse des traditions antagoniques n'aurait pas été possible. De Gaulle, même si élevé dans une famille sympathisant avec la monarchie, professe un patriotisme d'État et il accepte la république comme un moyen durable de l'existence de la France. Ses idées mûrissent sous l'influence des nationalistes républicains, tels que Charles Peguy et Maurice Barres, et non pas sous celle des idées monarchiques. Ils deviennent d'ailleurs l'inspiration pour le patriotisme de Ch. de Gaulle, un patriotisme acceptant la république, inclusif par rapport aux différentes traditions idéologiques et orienté sur un renforcement de l'État comme outil assurant la puissance de la France. De Gaulle pense alors non seulement à concilier la tradition monarchique avec la tradition républicaine, mais il pense avant tout à une république intégrant de différentes familles idéologiques. La façon dont on comprenait les obligations chrétiennes dans le domaine public favorise également l'acceptation du concept. Dans un esprit de tradition catholique libérale « Correspondant» trouve que les idées chrétiennes ne doivent pas être condamnées à l'échec dans un monde constitué du patrimoine de la Révolution.

Durant la Seconde Guerre mondiale, de Gaulle en qualité du Chef de la France Libre saura fermement consolider la tradition républicaine au moment du conflit avec le régime de Vichy. Dans les mémoires cités il peut donc écrire qu'en 1940 il fait « sortir la République du tombeau », une république abandonnée par la majeure partie de l'élite politique. Dans les années 1944-46 en qualité du chef du gouvernement provisoire, il fait des principes républicains la base pour la France d'après guerre. Durant cette période de Gaulle développe un modèle étatiste de l'économie, forme le caractère social de la République française. Ces décisions deviennent par la suite la base de la constitutionnalisation des principes républicains et la base également des références à la Déclaration des Droits de l'Homme et du Citoyen de 1789, faites de manière explicite dans les deux constitutions d'après guerre. La $\mathrm{V}^{\mathrm{e}}$ République pouvait donc être créée uniquement à l'issue d'un changement institutionnel dans le cadre d'une axiologie républicaine. 